This article is published as: Vanmaercke M, Poesen $\mathrm{J}$, Verstraeten $\mathrm{G}$, de Vente $\mathrm{J}$, Ocakoglu F (2011) Sediment Yield in Europe: spatial patterns and scale dependency. Geomorphology 130: $142-161$.

\title{
Sediment yield in Europe: spatial patterns and scale dependency
}

Matthias Vanmaercke ${ }^{a, b, *}, J_{e a n}$ Poesen $^{a}$, Gert Verstraeten $^{\mathrm{a}}$, Joris de Vente ${ }^{\mathrm{c}}$, Faruk Ocakoglu ${ }^{\mathrm{d}}$

${ }^{a}$ Division of Geography, K.U.Leuven, Celestijnenlaan 200 ${ }^{\mathrm{E}}, 3001$ Heverlee, Belgium;

${ }^{\mathrm{b}}$ Fund for Scientific Research-Flanders, Belgium

c Estación Experimental de Zonas Áridas, EEZA-CSIC, Desertification and Geoecology Department, Almeria, Spain;

${ }^{\mathrm{d}}$ Eskişehir Osmangazi University, Department of Geological Engineering, Eskişehir, Turkey.

* Corresponding Author: matthias.vanmaercke@ees.kuleuven.be, Telephone: +32/16/32.64.20

\begin{abstract}
Our understanding about the regional variation of Sediment Yield (SY) in Europe and its scale dependency currently relies on a limited number of data for mainly larger river systems. $S Y$ is the integrated result of all erosion and sediment transporting processes operating in a catchment and is therefore of high value for environmental studies and monitoring purposes. Most global assessments of $S Y$ consider catchment area $(A)$, climate and topography as the main explanatory variables. However, it is still unclear if these factors also control regional variations of $S Y$ within Europe. This paper aims at bridging this gap. Therefore, we i) present a large database of $S Y$-values which was constructed through an extensive literature review; ii) describe the spatial patterns of $S Y$ across Europe; and iii) expore its relation with $A$, climate, and topography.
\end{abstract}


In total, sediment yield data from 1794 different locations throughout Europe were collected (507 reservoirs and 1287 gauging stations), representing a minimum of 29203 catchmentyear data. Only $S Y$-data measured at gauging stations or derived from reservoir siltation rates over a period of minimum one year were included in the database. This database comprises a large range of catchment areas $(A)$ : i.e from small upland catchments $\left(\geq 0.01 \mathrm{~km}^{2}\right)$ to major European river basins $\left(\leq 1360000 \mathrm{~km}^{2}\right)$. An overview of the collected $S Y$-data is provided and sources of uncertainty on the available data are discussed.

Despite potentially large uncertainties on several of the individual $S Y$-values,_analysis of this database indicates clear spatial patterns of $S Y$ in Europe. The temperate and relatively flat regions of Western, Northern and Central Europe generally have relatively low $S Y$-values (with ca. $50 \%$ of the $S Y<40 \mathrm{t} \mathrm{km}^{-2} \mathrm{y}^{-1}$ and ca. $80 \%$ of the data $<200 \mathrm{t} \mathrm{km}^{-2} \mathrm{y}^{-1}$ ), while Mediterranean and Mountainous regions generally have higher $S Y$-values (with around $85 \%$ of the $S Y$-data $>40 \mathrm{t} \mathrm{km}^{-2} \mathrm{y}^{-1}$ and more than $50 \%$ of the data $>200 \mathrm{t} \mathrm{km}^{-2} \mathrm{y}^{-1}$ ). These differences are attributed to a combination of factors, such as differences in climate, topography, lithology and land use. Although larger differences in $S Y$ were found between the climatic regions than between topographic zones, it is currently difficult to identify the individual importance of the various controlling factors of $S Y$.

$S Y$-A relationships were calculated for the entire dataset and for subgroups stratified according to measurement method (gauging stations or reservoir surveys), range of the catchment area, climatic region, topographic zone of the river outlet, and major European river system. Although typically a negative relationship between $S Y$ and $A$ is expected due to a decrease in topsoil erosion rates on more gentle slopes and an increase in sediment deposition with an increase in catchment size, this relationship was found to be generally very weak and subject to a lot of scatter. Furthermore, results illustrate important differences in scale dependency: whereas a weak but significant negative trend is generally observed for the temperate and 
relatively flat regions, no significant or even positive trends were observed in mountain regions and Mediterranean Europe. When only larger river catchments (i.e. $>100 \mathrm{~km}^{2}$ and especially $>10000 \mathrm{~km}^{2}$ ) are considered, catchment area exerted a larger control on $S Y$. These findings confirm previous studies and indicate that the relationship between $S Y$, spatial scale and other controlling factors is often complex and non-linear.

\section{Introduction}

Soil erosion by water has been intensively studied in Europe over the laste decades (for an extensive overview see Boardman and Poesen, 2006) and is considered as one of the main threats to soil quality and productivity (EC, 2002; MEA, 2005). This research has led to a better understanding of the spatial patterns and intensity of water erosion processes at the hillslope scale in Europe (e.g. Kosmas et al., 1997; Kirkby et al., 2004; Poesen et al., 2006; Cerdan et al., 2010).

Area-specific sediment yield $\left(S Y, \mathrm{t} \mathrm{km}^{-2} \mathrm{y}^{-1}\right.$, i.e. the quantity of sediment reaching the catchment outlet per unit of time and per unit of area) at the catchment scale has also received considerable attention as it is crucial for many issues, such as capacity loss of reservoirs, damage to infrastructure, sedimentation of estuaries and harbours, coastal erosion, river delta development, eutrophication problems, the transportation of pollutants and damage to ecological habitats (e.g. Woodward, 1995; Owens et al., 2005; WCD, 2005; Rekolainen et al., 2006; Verstraeten et al., 2006). In addition, in drier environments $S Y$ can be an important desertificantion indicator (Vanmaercke et al., 2011).

Numerous papers have investigated the relationship between $S Y$ and various physical factors, such as climate, topography and catchment area, which are generally considered to be the dominant controlling variables at a global scale (e.g. Fournier, 1969; Jansen and Painter, 1974; Walling and Kleo, 1979; Milliman and Meade, 1983; Milliman and Syvitski, 1992; 
Dedkov and Moszherin, 1992; Einsele and Hinderer, 1997; Syvitski and Milliman, 2007). Several studies indicated, however, that other factors such as lithology and land use may control SY at a local scale (e.g. Bruijnzeel, 2004; Nadal-Romero et al., 2011).

Especially the scale dependence of $S Y$ has received considerable attention. A negative relationship is generally expected between $S Y$ and catchment area $\left(A, \mathrm{~km}^{2}\right)$ due to a decrease in topsoil erosion rates on more gentle slopes and an increased probability of sediment deposition with an increase in catchment size (e.g. Dendy and Bolton, 1976; Walling, 1983). Catchment area is therefore often considered as the most important explaining factor of $S Y$. Nevertheless, this relation can be strongly influenced by local factors, such as land cover, lithology, topography and human impacts, or the scale-dependent contribution of different erosion processes (de Vente and Poesen, 2005; de Vente et al., 2007). Moreover, the relationship between $S Y$ and $A$ may change over time (Walling, 1983). Therefore, catchment area is in fact only a black-box parameter (e.g. Verstraeten and Poesen, 2001).

Over the last decades, $S Y$-data have been collected for various regions and for catchments of various sizes. Several authors have made global inventories of available $S Y$-data. Table 1 lists some of these datasets, reporting the total number of $S Y$-observations as well as the number of observations for Europe. Although many of these datasets contain large numbers of $S Y$-data, the data for European catchments are generally limited or correspond only to larger river systems (i.e. $>100 \mathrm{~km}^{2}$ ). An important problem is the lack of an overview of available $S Y$ data for Europe. Whereas for the USA, an extensive standardized gauging network exists throughout the country, providing suspended sediment load data for more than 1400 catchments (monitored by the USGS, e.g. Gray and Gartner, 2010), as well as a detailed database on bathymetric surveys in more than 1800 reservoirs (e.g. Gray et al. 2010), SYmeasurements in Europe are carried out by various institutions for different purposes. The results of these measurements are therefore scattered over various scientific papers, technical 
reports and $\mathrm{PhD}$ theses, or remain unpublished. Furthermore, many $S Y$-data have been published recently and are therefore not included in earlier established global compilations. Current analyses of the regional patterns of $S Y$ at the European scale therefore do not fully exploit available $S Y$-data and are mostly based on a limited number of observations, focussing mainly on the larger river systems (e.g. Walling and Webb, 1983; Milliman, 2001; Owens and Batalla, 2003; Delmas et al., 2009). A relatively large dataset with SY-data for 392 catchments in Europe was compiled by Verstraeten et al. (2006), but provides no complete overview of the available data as it only consists of $S Y$ estimates derived from reservoir siltation rates. Furthermore, the study of Verstraeten et al. (2006) was mainly descriptive and provides only a rough analysis of the spatial patterns and scale-dependency of $S Y$ in Europe. As a result, our understanding of the regional variation of $S Y$ and its relationship with spatial scale and other environmental variables within Europe is very limited.

This study aims to address this knowledge gap by compiling available $S Y$-data in Europe and by providing a first exploration of the collected data at the continental scale, focussing on the potential importance of catchment area, topography and climate. The specific objectives are: i) to provide an overview of available $S Y$-data in Europe; ii) to explore the spatial variability of $S Y$ in Europe; iii) to explore the scale dependency of $S Y$ in Europe; and iv) to discuss the accuracy of these results and to provide suggestions for further research.

\section{Data collection and preparation}

\subsection{Construction of the sediment yield database}

Based on an extensive literature review, sediment yield data of European rivers were collected from scientific publications, MSc. and $\mathrm{PhD}$. theses and reports from hydrological institutes. The area considered in this study is indicated in Fig. 1. Only sediment yield data that were derived from measurements at a gauging station or from reservoir siltation rates, over a 
measuring period of at least one year and for catchments with an area of at least $0.01 \mathrm{~km}^{2}$ were considered. This catchment area threshold was arbitrarily chosen as smaller catchments can be expected to correspond almost entirely to hillslope systems with no central drainage system. Furthermore, very few studies reported measured $S Y$ for catchments smaller than 0.01 $\mathrm{km}^{2}$.

Each entry in the database corresponds to one catchment for which $S Y$ has been measured and contains at least the name of the river, the measuring method (observation at a gauging station ('GS') or derived from a reservoir sedimentation rate ('R')), the location of the GS or R (i.e. the catchment outlet), the catchment area as reported in the original publication, the areaspecific sediment yield, and the measuring period. For several entries, the measuring period was not reported but indicated to be longer than one year. In these cases, the measuring period was considered to be one year in our database. The coordinates of the catchment outlets were based on the originally reported coordinates. If original coordinates were unavailable, an assessment was made, based on the description of the catchment outlet in the publication, using Google ${ }^{\mathrm{TM}}$ Earth. If the catchment outlet could not be determined sufficiently accurate (e.g. when no location name was reported), the entry was not included in the database. Because many $S Y$-data are reported in several sources, the database was checked for duplicate entries. Two entries were considered as duplicates if they had the same catchment outlet and (therefore) the same $A$. In such case, only the most reliable entry was included. This was generally considered to be the entry with the longest measuring period. If the measuring periods were equal or unknown, the source that provided the most detailed information on the catchment outlet and measuring technique was included.

The GS-entries in the database comprise $S Y$-data, measured and calculated with a wide variety of techniques and procedures. For GS-entries, only the suspended sediment yield was 
considered, as bedload data were unavailable for most gauging stations and dissolved load is beyond the scope of this study.

For R-entries, $S Y$ was estimated as (Verstraeten and Poesen, 2002):

$$
S Y=100 \frac{S V \times d B D}{T E \times A}
$$

With $S V\left(\mathrm{~m}^{3} \mathrm{y}^{-1}\right)$ being the annual sedimentation rate in the reservoir, $d B D\left(\mathrm{t} \mathrm{m}^{-3}\right)$ the dry sediment bulk density and $T E(\%)$ the sediment trap efficiency of the reservoir. In many cases, not all variables of Eq. 1 were known. Some sources did only report $S V$ but not $d B D$. For these entries a bulk density of $1.12 \mathrm{t} \mathrm{m}^{-3}$ was assumed, i.e. the average $d B D$ of a large dataset of reservoir siltation rates (Verstraeten et al., 2006). Also TE was unknown in most cases (only for 9 reservoirs an accurate estimate was available). Generally, the $T E$ of a larger reservoir is best predicted using the equation of Brune (1953), which relates $T E$ to a ratio of the reservoir storage capacity and the annual inflow (Verstraeten and Poesen, 2002). However, for the majority of the reservoirs, no information on annual inflow was available. Hence, missing $T E$-values were estimated using an empirical equation proposed by Brown (1943) in Verstraeten and Poesen (2000):

$T E=100\left(1-\frac{1}{1+0.0021 D \frac{C}{A}}\right)$

Where $C$ is the reservoir storage capacity expressed $\left(\mathrm{m}^{3}\right)$ and $D\left(\mathrm{~km}^{2} \mathrm{~m}^{-3}\right)$ a coefficient which depends on the operational characteristics of the reservoir. Values of $D$ range between 0.046 and 1, with an average value of $0.1 \mathrm{~km}^{2} \mathrm{~m}^{-3}$ (Verstraeten and Poesen, 2000). As the actual values of $D$ were unknown, the average value was used to estimate all missing trap efficiencies.

\subsection{Classification of the data}


To analyse the collected data, entries were classified according to climate, topography and river basin. To classify the data according to climate, the LANMAP2 climatic classification was used (Mücher et al., 2006; Metzger et al., 2005). This classification is based on a principal component analysis of twenty relevant variables (e.g. monthly air temperature, monthly precipitation, hours of sunshine, altitude ...) and showed good agreement with other European classifications. Fig. 1 shows the climatic regions of Europe according to this classification. Using this subdivision, we classified all $S Y$-data into eight climatic groups, based on the location of the catchment outlets. As some catchments are located in more than one climatic region, their assignment to the climatic region of the outlet may be disputable. However, this holds mainly for larger catchments. It was estimated that maximum $30 \%$ of the catchments cover more than one climatic region. For catchments smaller than $1000 \mathrm{~km}^{2}$ this is less than $5 \%$, while $80 \%$ of the catchments larger than $10000 \mathrm{~km}^{2}$ are potentially situated in more than one climatic region.

Similar to the climatic classification, each entry was also assigned to a topographic class, based on the location of the catchment outlet: Lowlands (0-100 m a.s.1.), Hills (100-500 m a.s.1.), Low Mountain Ranges (500-1500 m a.s.1.), High Mountain Ranges (1500-2500 m a.s.1.) and Alpine Mountain Ranges (2500-5000 m a.s.1.). These five classes also correspond to the topographic subdivision of Europe according to the LANMAP2 classification (Mücher et al., 2006).

$S Y$-data were also grouped according to the major river basin in which they are located. This was done by combining the locations of the catchment outlets with a map of the major European river catchments (Bredahl and Sousal, 2006).

\section{Description of the database}


The SY-database, consists of 1794 entries (507 R- and 1287 GS-entries). Table 2 gives an overview per country, while Fig. 1 displays the spatial coverage of the collected data. This map illustrates that some areas are densely covered with clusters of $S Y$-data (e.g. Romania, Italy, Spain, and Turkey), while for other regions no or very few data were found (e.g. central France, Ireland, Belarus and Lithuania). For some regions, more $S Y$-data exist, but were not available for this study (e.g. for Ukraine: Kovalchuk and Vishnevskiy, 2004). The overview presented here is therefore not complete but most likely covers the majority of available $S Y$ data in Europe.

The sum of all measuring periods comprises a minimum of 29203 catchment-year data. Fig. 2 indicates the cumulative distribution of the GS- and R-entries according to their measuring period. The average measuring period for GS-entries is 12 years (13.2 years when entries with unknown measuring period are excluded) and 27.1 years for R-entries (32.5 years without entries with an unknown measuring period). Fig. 3 displays the temporal coverage of the data, indicating the approximate number of entries that include a certain year in their measuring period. Only the entries for which both the start and end date of the measuring period were known could be included $(\mathrm{n}=1490)$. This figure indicates that most GS-data were collected between 1950 and 2000, except for the Mediterranean region, for which many data were collected between 1930 and 1950. Many R-entries date back longer. 36 R-entries date back before 1900, while 138 R-entries date back before 1950. Most of the oldest reservoirs are situated in England.

Fig. 4 shows the frequency distribution of the entries and catchment-years according to their catchment area. Subdivisions are made according to measuring method and climatic region. These histograms indicate that most catchments have $100<A<10000 \mathrm{~km}^{2}$. Data from catchments, smaller than $10 \mathrm{~km}^{2}$ and especially smaller than $1 \mathrm{~km}^{2}$ are relatively rare. The distribution of the number of catchment-years corresponds more or less to the distribution of 
the number of entries, except for entries with $1<A<10 \mathrm{~km}^{2}$. This group has a relatively larger number of catchment years as it includes several old reservoirs in England for which long-term $S Y$-values could be calculated. The Continental climatic region has the largest number of entries $(n=608)$, followed by the Mediterranean region $(n=540)$. The Atlantic $(n$ =282), Alpine $(n=157)$, Boreal $(n=93)$ and Anatolian $(n=70)$ regions are also relatively well presented, while the Steppic $(n=37)$ and especially the Arctic $(n=7)$ regions are poorly represented.

\section{Analysis of the sediment yield database}

\subsection{Spatial patterns of sediment yield in Europe}

Table 3 gives descriptive statistics of the collected data. When all data are considered the median and mean SY of R-entries are larger than those for GS-entries. Non-parametric Kruskal-Wallis tests indicate that the distribution of $S Y$-values for R-entries differs significantly $(\alpha=0.05)$ from the $S Y$-distribution based on GS-entries. The differences in medians and means are, however, relatively small compared to the large range of $S Y$ observations and are not necessarily attributed to differences in measuring method.

Fig. 5 displays a map of all $S Y$-values, grouped into three classes $\left(<40 \mathrm{t} \mathrm{km}^{-2} \mathrm{y}^{-1}, 40-200 \mathrm{t}\right.$ $\mathrm{km}^{-2} \mathrm{y}^{-1}$ and $>200 \mathrm{t} \mathrm{km}^{-2} \mathrm{y}^{-1}$ ). The boundaries of these classes were determined so that each class contained roughly $33 \%$ of the total number of entries. As the entries in the database comprise a large range of measuring procedures, measuring periods, catchment areas and catchment characteristics, differences in $S Y$ can not always be explained unambiguously. However, the use of only three arbitrary classes and the large number of observations make it possible to reveal some general patterns of $S Y$ in Europe. This map indicates that large parts of central, Western and Northern Europe are generally characterized by low $S Y$-values $(<40 \mathrm{t}$ $\left.\mathrm{km}^{-2} \mathrm{y}^{-1}\right)$. In Southern Europe $S Y$-values above $40 \mathrm{t} \mathrm{km}^{-2} \mathrm{y}^{-1}$ and even above $200 \mathrm{t} \mathrm{km}^{-2} \mathrm{y}^{-1}$ are 
much more frequent. Furthermore, several mountain ranges in Europe, such as the Alps, Apennines and Carpathians, can be clearly distinguished since most $S Y$-values there are above 40 and even $200 \mathrm{t} \mathrm{km}^{-2} \mathrm{y}^{-1}$.

Fig. 6 displays the cumulative frequency distribution of $S Y$ per climatic region. Table 3 reports descriptive statistics of the $S Y$-values per climatic region. This comparison indicates some clear differences: the Mediterranean and Alpine regions generally have the highest $S Y$ values, while the Atlantic and Boreal regions generally have the lowest $S Y$. The Anatolian and Continental regions have intermediate values. For the Steppic and Arctic regions, the number of observations is too low to draw any conclusions. When the SY-data are grouped according to topographic zone (Fig. 6, Table 3), results indicate that the $S Y$-distribution for catchments in lowlands plots generally below the $S Y$-distributions for catchments in hills and mountain ranges. Hilly catchments also have generally lower $S Y$-values than mountain ranges, but no clear differences between low, high and alpine mountain ranges can be observed. In general, $S Y$-distributions differ less between topographic zones than between climatic regions.

\subsection{Scale dependency of sediment yield and its regional variation}

A graph of the $S Y$ versus the $A$ of all entries reveals that the scatter is generally very large, with $S Y$ often ranging over 5 to 6 orders of magnitude for a given $A$ (Fig. 7). It can be noticed that the variation in $S Y$ is generally lower for larger catchment areas: while the minimum values remain more or less constant, maximum values generally decrease with increasing A. To further analyze the scale-dependency of $S Y$ in Europe, $S Y$ - $A$ relationships were calculated. These regressions were of the type:

$$
S Y=\mathrm{a} \times A^{\mathrm{b}}
$$

with a and b empirical constants. Regressions were calculated in two ways: as 'normal' regressions, where all $S Y$ observations were considered equally important. This procedure 
corresponds to the method used in other studies (e.g. de Vente et al., 2007). SY-values can, however, vary significantly from year to year. As a result, $S Y$-values that are based on longer measuring periods can be expected to better represent the long-term average. Therefore, also 'weighted' regressions were calculated by attributing a weight to each observation, corresponding to the square root of the length of the measuring period (expressed in years). This was done in accordance to the central limit theorem which implies that the variation on a set of random observations is inversely proportional to the square root of the number of observations (Tijms, 2004). Table 4 reports all regression results, based on both the weighted and the normal method. However, as these weighted regressions are expected to be more reliable, all trend lines in the figures are based on the weighted regression results.

When all data are considered (Fig. 7, Table 4), a very weak but significant $(\alpha=0.05)$ negative correlation is found. A slightly stronger, but still very weak negative correlation is found when only the GS-data are considered. For all R-data, no significant relationship was observed. Further, $S Y$-A relationships were calculated for all $S Y$-data with an $A<100 \mathrm{~km}^{2}$, $100<A<10000 \mathrm{~km}^{2}$, and $A>10000 \mathrm{~km}^{2}$ (Table 4, Fig. 7). For catchments with $A<100$ $\mathrm{km}^{2}$ no significant relationship was found, while for catchments with $100<A<10000 \mathrm{~km}^{2}$ and catchments with $A>10000 \mathrm{~km}^{2}$, significant relationships were observed. The b-exponent of Eq. 3 becomes increasingly negative as the catchment area of the considered subset increases, pointing at a stronger decrease of $S Y$ with increasing $A$. Nevertheless, the associated $\mathrm{r}^{2}$-values are also very low (Table 4).

Fig. 8 displays the $S Y$ - $A$ trends for all European river catchments for which more than $20 S Y$ observations were available. Most rivers in northern, eastern and western Europe, except the Ouse (Yorkshire, United Kingdom), have a significantly decreasing trend (Table 4). However, for rivers in Southern Europe (i.e. the Ebro, Po and Segura) an insignificant, positive relationship was found. Similar results were obtained with the 'normal' regression method. 
The results of the $S Y$ - $A$ regressions according to the climatic region of the catchment outlets, are given in Fig. 9 and Table 4. These results correspond relatively well to the observed cumulative SY-distributions (Fig. 6): the relationships of the Boreal and Atlantic regions plot the lowest, while those of the Mediterranean and Alpine regions generally plot the highest. A significant negative relationship was found for the Atlantic, Boreal and Continental regions for both the weighted and normal regression method (Table 4). However, the corresponding $\mathrm{r}^{2}$-values are very low. Also for the Steppic region, a significant negative relationship was found, but this regression is based on a rather limited number of observations and only includes catchments with a relatively large $A$. With the weighted regression method the Mediterranean and Alpine regions do not show a significant relationship. For the normal regression, however, the relationship for the Mediterranean region is weakly significant and negative. This is mainly due to some very small (i.e. $<0.1 \mathrm{~km}^{2}$ ) catchments situated in badlands with high $S Y$-values but short measuring periods $\left(1600-8000 \mathrm{t} \mathrm{km}^{-2} \mathrm{y}^{-1}\right.$, Descroix, 1994; Olivry and Hoorelbeck, 1989). The Arctic and Anatolian regions seem to have a positive $S Y$ - $A$ trend, but the relationship for the Artic region is not significant as it is based on very few observations. Also for the Anatolian region the trend is only barely significant $(\mathrm{p}=0.049)$ when the weighted regression method is applied and insignificant for the normal method.

Fig. 10 displays the regressions per climatic region, further subdivided according to the measuring method (GS or R). Regression details are given in Table 4. Although the number of observations and the range of catchment areas are sometimes too small to draw conclusions, these results clearly indicate that for a given A, R-entries have generally higher $S Y$-values than GS-entries. Nevertheless, the observed pattern of Fig. 9 remains more or less consistent for both GS- and R-data. Only for the R-entries in the Atlantic region an 
insignificant trend was observed, while for GS-entries in the Mediterranean regions a significant negative trend was found.

Fig. 11 displays the $S Y-A$ relationships for all catchments, grouped according to the topographic zone of the catchment outlets. Lowlands and hills reveal a significant negative relationship, although the associated $\mathrm{r}^{2}$-values were very low (Table 4). For low, high and alpine mountain ranges, no significant relationship was found. The slopes of these relationships (b-values in Table 4) further suggest that $S Y$ tends to decrease more with increasing $A$ in lowlands than in the hills or mountainous ranges.

\section{Discussion}

\subsection{Availability of sediment yield data}

Fig. 1 indicates important differences in $S Y$-data availability within Europe. Whereas some regions are densely covered with gauging stations and/or reservoirs, other regions in Europe are poorly represented. Although more $S Y$-data probably exist for several of these regions, this literature review indicates that for some areas there are currently very few $S Y$-data available (e.g. the Arctic regions and Ireland). Furthermore, the $S Y$ database reveals relatively few data for small catchments, (i.e. $<100 \mathrm{~km}^{2}$ ) and especially for catchments smaller than 1 $\mathrm{km}^{2}$ (Fig. 4). While many of the $S Y$-data for medium-sized and larger catchments (i.e. $>100$ $\mathrm{km}^{2}$ ) were collected by national agencies, most $S Y$-data for smaller catchments were collected for specific research purposes and are mainly published in scientific publications.

Regarding the temporal distribution, Fig. 3 clearly indicates that most data were collected between 1960 and 1990, with a peak around the 1980s. After this peak, the number of R- and especially GS-observations strongly declines. This sharp decrease is most likely related to the deterioration of many nation-wide gauging networks in the '90s and corresponds to a globally observed decrease of runoff gauging stations since the '80s (e.g. Vörösmarty, 2002). 


\subsection{Measuring method and quality of sediment yield data}

The data considered in this study cover a wide range of measuring techniques and periods. As a result, the $S Y$-data are of variable quality and have different degrees of uncertainties, depending on various factors. The total uncertainty on SY-values for R-entries is determined by the uncertainties on each of the factors in Eq. 1. (i.e. the uncertainty on $S V, d B D, T E$ and A). The uncertainty on the annual sedimentation volumes were impossible to assess, as these mainly depend on the survey and interpolation method of the bathymetric surveys (Verstraeten and Poesen, 2002) and information on these methods or their accuracies was never reported.

Uncertainties on the dry bulk densities are probably small for the R-entries with measured $d B D$-values. A study of 13 ponds in Belgium, indicated that $d B D$ varies relatively little within a reservoir, with coefficients of variation generally in the order of $10 \%$ (Verstraeten and Poesen, 2002). For 166 out of the 506 R-entries, however, $d B D$ was not known and a value of $1.12 \mathrm{t} \mathrm{m}^{-3}$ was assumed, i.e. the average $d B D$ of a global dataset of reservoir siltation rates (Verstraeten et al., 2006). For these R-entries, the induced uncertainty is of course larger. All measured $d B D$-values in this global dataset ranged between 0.14 and $1.7 \mathrm{t} \mathrm{m}^{-3}(\mathrm{n}=528)$. If we consider this range as representative for the range of $d B D$-values that can occur in a reservoir, this means that applying a dBD of 1.12 can overpredict the actual SY with a factor 8 or underpredict the SY with a factor 0.66 . However, for most R-entries, induced uncertainty will, be smaller: $95 \%$ of the $d B D$-values in this global datasets range between 0.35 and $1.5 \mathrm{t} \mathrm{m}^{-3}$ and $68 \%$ between 0.87 and $1.4 \mathrm{t} \mathrm{m}^{-3}$.

The estimated $T E$-values also induce uncertainty on the SY-values of R-entries. A detailed overview of various procedures to estimate $T E$ indicated that Eq. 2 performs satisfying to estimate the long-term $T E$ of larger reservoirs (Verstraeten and Poesen, 2000). Although $T E$ - 
values estimated with this equation may deviate from the actual long-term $T E$, e.g. because the value of $D$ was unknown, applying these estimates is justified: not applying a correction for $T E$ would systematically lead to an underestestimation of $S Y$ for R-entries. However, the uncertainty associated with the unknown trap efficiencies is expected to be relatively small: less than $20 \%$ of the R-entries have an estimated $T E$ of $50 \%$ or less, while more than half of the reservoirs have estimated TEs of $90 \%$ or more. Also the arbirarly $D$-value of 0.1 in Eq. 2 has little effect on most estimated TEs. For an R-entry with a C/A-ratio of $8 \times 10^{4} \mathrm{hm}^{3} \mathrm{~km}^{-2}$ (the median C/A-ratio), the estimated TE is $95 \%$. This value would change to $89 \%$ if the minimum $D$-value is used and to $99 \%$ if the maximum $D$-value is used.

The uncertainty for GS-observations also depends on various factors, which have been discussed in various studies. For example, Steegen and Govers (2001) report errors on SY in the range of $20 \%$ if suspended sediment concentration $(S S C)$ is measured at a fixed point in the cross-section. These errors are explained by a concentration gradient in the flow crosssection and depend on flow characteristics as well as on the grain-size distribution of the sediments, but can be avoided by taking $S S C$-samples in a depth-integrated way (Steegen and Govers, 2001).

Teixeira and Caliari (2005) report errors of 20-30\% on SSC-estimates, derived from turbidity measurements. Also the timing and frequency of sampling has a significant impact on the reliability of the $S Y$-estimate. Uncertainty generally increases if the sampling frequency decreases, but depends on the used load estimate procedure and catchment characteristics (e.g. Webb et al., 1997; Phillips et al., 1999; Moatar et al., 2006). The magnitude of these errors is therefore difficult to assess, but can be larger than $100 \%$ when sampling was carried out very infrequently (e.g. once per month).

Various studies indicate that inadequate sampling schemes and sediment load estimate procedures not only lead to larger uncertainties, but also to a probability of underestimating 
the actual $S Y$ at gauging stations. Steegen et al. (2000) found that time-spaced sampling underestimated the $S Y$ of a 250 ha catchment in central Belgium by $20-35 \%$ compared to flow-proportional sampling ('storm chasing'). Ferguson (1986) illustrated that sediment loads, derived from logarithmically transformed data, may underestimate the true sediment load with errors up to $50 \%$ due to statistical considerations. Correction factors or the use of non-linear regression techniques can avoid this bias (e.g. Asselman, 2000). However, these correction factors are not always applied. Also low sampling frequencies not only induce uncertainties but tend to underestimate the actual load. This was observed for load estimates based on rating curves (e.g. Webb et al., 1997), as well as on discharge-weighted mean sediment concentrations (e.g. Moatar et al., 2006). Furthermore, the GS-entries in this study only include suspended sediment loads, while $S Y$-estimates derived from reservoir surveys also include bedload. A review by Turowski et al. (2010) illustrates that bedload may be a substantial fraction of the total load, especially for sand-bed rivers (30-50\%) and smaller catchments. However, the importance of bedload for individual rivers can currently not be predicted accurately (Turowski et al., 2010).

The inter-annual variability of $S Y$ also induces uncertainties. The confidence in mean values that may be biased by the presence or absence of extreme events is a classical problem in fluvial geomorphology, especially for short-term time series (e.g. Kirkby, 1984; GonzalezHidalgo et al., 2009). As GS-entries generally have shorter measuring periods than R-entries (Fig. 2), uncertainties due to inter-annual variation are expected to be larger for GS-entries. Finally, catchment areas are also subjected to uncertainties and potentially induce errors on the $S Y$-values. Accuracies of the reported $A$-values are rarely reported, but are expected to be relatively small (Verstraeten and Poesen, 2002).

This non-exhaustive overview indicates that all $S Y$-values are subjected to several sources of uncertainties. However, for none of the $S Y$-entries it was possible to assess the total 
uncertainty, as this depends on various unknown site- and method-specific factors. Nevertheless, considering all the discussed sources of uncertainty suggests that total uncertainties may rise well over $100 \%$ for some $S Y$-entries (e.g. for GS-observations with a very short measuring period and low SSC sampling frequency).

\subsection{Reliability of the obtained spatial patterns and scale-dependency results}

Given the potential errors associated with the reported $S Y$-data, the results discussed in section 4 need to be interpreted with caution. Inaccurate $S Y$-data could partly explain why most $S Y$ - $A$ relationships have such a poor correlation (Table 4). However, it can be expected that $S Y$ estimates will not differ more than one or two orders of magnitude from their actual values, while $S Y$ can vary up to six orders of magnitude for a given $A$ (Fig. 7). The observed variability is therefore clearly not only a result of measuring uncertainties, but also from other controlling factors of $S Y$. Moreover, the observed spatial patterns of $S Y$ are based on relatively large numbers of data, reducing the importance of possible measuring errors. For example, the discussed differences in cumulative frequency distribution between climatic regions are generally valid for $90 \%$ to $95 \%$ of the distributions, which often include more than 70 observations collected with various methods (Fig. 6). Furthermore, some entries in Fig. 5 may be attributed to a wrong $S Y$-class, but this would have only a limited effect on the discussed pattern.

The inter-annual variability of $S Y$ could also have an effect on the obtained results, because many entries have relatively short measuring periods (Fig. 2). This variability was partly taken into account by calculating weighted $S Y-A$ relationships. Nevertheless, analysis of the residues of both normal and weighted regressions revealed no correlation between the absolute values of the residues and the corresponding measuring periods. 
The very poor correlations between $S Y$ and $A$ for most of regressions (Table 4) therefore mainly indicate that other factors than $A$ exert a stronger control on $S Y$. Various studies have indicated that factors such as climate (e.g. Jansen and Painter, 1974; Wilson 1977; Jansson, 1982; Syvitski and Milliman, 2007), topography and tectonics (e.g. Milliman and Syvitski, 1992; Montgomery and Brandon, 2002), lithology (e.g. Woodward, 1995; Nadal-Romero et al., 2011), the presence of glaciers (e.g. Hallet et al., 1996; Hinderer and Einsele, 2001), land use and human impacts (e.g. Walling, 2006; Vanacker et al., 2007) and the presence of lakes and reservoirs (e.g. Vörösmarty et al., 2003; Walling, 2006) may have a large influence on catchment $S Y$. Many of these factors are not (explicitly) considered in the classifications used. For example, a visual comparison of Fig. 5 with maps indicating seismic activity in Europe (Cloetingh et al., 2005), revealed good correspondence: high $S Y$-values generally occur in tectonically active regions, such as the Alps, the Pyrenees, the Apennines and Anatolia. Also (natural) lakes may have a significant influence on the observed patterns, since they trap large fractions of eroded sediments (e.g. Einsele and Hinderer, 1997). Around three quarters of the more than 500000 natural lakes larger than $0.01 \mathrm{~km}^{2}$ in Europe are located in the Boreal region (Stanners and Bourdeau, 1995), which may help explaining the low $S Y$-values for this region (Fig. 6). Furthermore, results are based on data, collected over different periods of time (Fig. 3). Variation in $S Y$ can therefore also partly be attributed to temporal variations in weather conditions or landuse. For example, several countries of Eastern Europe have undergone significant land use changes during the last decades (e.g. Van Rompaey et al., 2003).

An important consideration is that correlations exist between several of these factors. As Table 5 illustrates, many considered climatic regions concur strongly with specific topographic zones, and measuring methods (GS or R). For example, for the Boreal region, most catchment outlets are located in hills and lowlands. Based on the classifications used, it 
is impossible to assess if the generally low $S Y$-values for this region (Fig. 6) are mainly a result of climatic or topographic factors, as lowlands and hills were also characterized by generally lower $S Y$-values (Fig. 6). Similar considerations can be made for other regions: the Alpine, Anatolian and Mediterranean climatic regions are characterized by larger $S Y$-values, but also by generally more entries located in mountainous areas (Table 5). It could be argued that a further subdivision of the data, i.e. according to both climatic region and topographic zones, would allow a better identification of the controlling factors. However, such approach was found unreliable since for most of these resulting groups, the number of $S Y$-observations and the range of catchment areas would be very low, leading to even less reliable $S Y-A$ relationships (e.g. De Boer and Crosby, 1996).

Interpretation of the obtained spatial patterns and $S Y-A$ relationships is not only impeded by covariation between explanatory variables, but also by their correlation with the measuring methods. For example, most entries in the Boreal region where derived from GSobservations, while the Mediterranean and Alpine region have relatively more R-entries (Table 5). As discussed in the previous section, GS-entries have a relatively larger probability of underestimating the actual $S Y$, which may contribute to the observed differences. This is also indicated in Fig. 10, where for almost every climatic region, the $S Y$ - $A$ regression based on R-data plots above the regression line based on GS-data. However, also these differences can not merely be attributed to differences in measuring method because reservoirs are probably more likely to occur in areas with a higher relief potential or erosion risk, compared to gauging stations (e.g. Verstraeten and Poesen, 1999). Furthermore, it can be expected that bathymetric surveys are more frequently conducted in reservoirs with a high sedimentation rate, which could also bias the results towards higher $S Y$-values for R-data. Also the difference in the $S Y$-A relationship for GS- and R-entries in Fig. 7 is most likely explained by both differences in measuring method, as well as by geographical factors (Table 5). Based on 
the available data, it is currently impossible to assess the precise impact of the different measuring methods on the obtained results. Nevertheless, observed differences between GSand R-data in Fig. 10 are generally less than one order of magnitude.

\subsection{Interpretation of the results and comparison with literature}

The analysis presented here confirm earlier studies that $S Y$-A relationships can certainly not be used straightforward for predictive purposes (e.g. Walling, 1983; de Vente and Poesen, 2005). Furthermore, differences in the cumulative frequency distributions (Fig. 6) or $S Y$ - $A$ relationships between climatic or topographic regions (Fig. 9, 10 and 11) can not merely be attributed to differences in either climate or topography, due to their correlation with other factors.

Nevertheless, important lessons can be learned from the obtained results. The climatic regions shown in Fig. 1 provide a meaningful subdivision of Europe in physical regions with different characteristics (Mücher et al., 2006; Metzger et al., 2005). Important differences in SY were observed between those regions which reflect at least partly differences in environmental characteristics (Fig. 5, 6). Previous studies, based on smaller datasets, reported similar patterns and also related these to various interrelated factors, such as climate, topography, lithology and land use (Jansson, 1988; Woodward, 1995; Walling and Webb, 1996; Milliman, 2001; Verstraeten et al., 2006). The importance of these factors is reflected in the very low correlation coefficients of the calculated $S Y$-A relationships for the entire dataset (Fig. 7).

$S Y-A$ relationships for catchments within the same region or with similar characteristics can yield stronger correlations, as this can reduce the effect of these other controlling factors. Several studies reported much stronger $S Y$-A relationships when only data of a specific region are considered (for a review: see de Vente et al., 2007). Also in this study better $S Y$ - $A$ relationships were found for some climatic regions (Fig. 9), topographic zones (Fig. 11) or 
river basins (Fig 8). However, the explained variance of these regressions remains low, and regressions for several regions or catchments were insignificant. The obtained relationships therefore mainly illustrate that $A$ explains only a small part of the observed variation in $S Y$ at a regional scale. Despite their low explaining power, the calculated $S Y$-A relationships also indicate important regional differences in scale dependency for Europe. Whereas weak but significant negative trends were found for most catchments in northern, westen and central Europe, this was generally not the case for catchments in southern Europe and mountain regions. This pattern remains more or less consistent when regressions were calculated according to climatic region (Fig. 9), river basins (Fig. 8) and topographic zone (Fig. 11), and for both the weighted and normal regressions (Table 4).

This finding is also in line with previous studies. de Vente and Poesen (2005) suggest that SY in Mediterranean environments can be expected to first increase with $A$, because of the increasing sediment contribution from different erosion processes. Whereas sheet and rill erosion processes are the major sediment producing processes at the plot scale $\left(A<10^{-3} \mathrm{~km}^{2}\right)$, other erosion processes such as gullies, landslides and river bank erosion may contribute significantly to $S Y$ as $A$ increases. Only when spatial scale further increases (i.e. $A>10^{2} \mathrm{~km}^{2}$ ), the effect of sediment sinks override the importance of these sediment sources, resulting in a gradual decline of $S Y$. The lack of a significant and continuously negative relationship for the Mediterranean (and Anatolian) region (Fig. 9) seems to confirm the conceptual model of de Vente and Poesen (2005). Further confirmation was found when a comparison between the collected $S Y$-data and a data set of soil loss rates, measured on runoff plots $\left(A<10^{-4} \mathrm{~km}^{2}\right)$ for a range of conventional land uses (Vanmaercke et al., 2011). Soil loss rates at the plot scale were found to be generally higher than catchment $S Y$ in Non-Mediterranean region, which corresponds to the common expectation that $S Y$ decreases with increasing $A$. For the Mediterranean region, however, $S Y$-values were generally larger than soil losses at the plot 
scale, illustrating the importance of other erosion processes than sheet and rill erosion in this region.

Also for mountain regions, the expected decrease in $S Y$ with increasing $A$ is probably overrided by the importance of other sediment-producing processes, explaining why no significant trend was found for the Alpine regions (Fig. 9) and mountain ranges (Fig. 11). Landslides, for example, can be expected to occur more frequently in mountain regions, due to their steep slopes and often higher tectonic activity (e.g. Korup, 2005; Montgomery and Brandon, 2002; Cloethingh et al., 2007). Although few quantitative data are available, it is known that landslides may contribute significantly to $S Y$ (e.g. Korup et al., 2004; Bathurst et al., 2005). The presence of glaciers can also have a major impact on $S Y$ and its scale dependence in mountainous catchments (e.g. Hallet et al., 1996; Hinderer and Einsele, 2001). Furthermore, it can be expected that mountain ranges have relatively fewer areas where sediments can be redeposited and stored compared to lowlands and hilly regions, as the possibility to redeposit sediments is strongly controlled by the local gradient. For example, a quantification of postglacial storage in the Alps, indicated that $90 \%$ of the areas where sediment is stored occurs in the lowest $25 \%$ of the mountain belt (Straumann and Korup, 2005). Similarly, the location of the dominant sediment source areas within a catchment can also exert an influence on the observed $S Y$-A trend (e.g. de Vente et al., 2007). Whereas for many rivers (e.g. the Rhône, originating in the Alps) the distance from the most important sediment source area to the outlet (and hence the probability of sediment redeposition) increases with increasing $A$, the Ebro and Po run more or less parallel to a mountain range (the Pyrenees and the Alps respectively). This may help explaining why for these two rivers, no significant negative $S Y$-A relationship was found (Fig. 8, Table 4).

The importance of local factors on $S Y$ can be expected to be smaller for large river systems (e.g. $A>10000 \mathrm{~km}^{2}$ ). Larger catchments generally consist of a patchwork of land uses and 
geomorphic units. Local conditions are therefore less likely to override general trends, as they often average out at larger scales. Furthermore, mean slope gradient generally decreases with increasing $A$ and the importance of sediment sinks can be expected to further increase (e.g. de Vente and Poesen, 2005). This is in line with our results. While no significant $S Y$ - $A$ trend was found for all catchments smaller than $100 \mathrm{~km}^{2}$, significantly negative trends were observed for catchments of $100-10000 \mathrm{~km}^{2}$ and for catchments $>10000 \mathrm{~km}^{2}$ (Fig. 7, Table 4). Although $\mathrm{r}^{2}$-values are still very low, the observed slopes of the regression equations are much steeper than most of the slopes for the other calculated $S Y-A$ relationships $(b=-0.28$ and -0.33 , respectively, Table 4). These values also agree more with the reported slope value of -0.5 that is often used for global prediction purposes and that was mainly based on observations for the largest river systems in the world (e.g. Syvitski et al., 2005; de Vente et al., 2007).

\section{Conclusions and scope for further research}

So far, studies assessing the regional variation of $S Y$ in Europe were based on a relatively limited number of $S Y$-data, focussing mainly on larger river systems. An overview of pan European patterns of SY and its relationship with topography, climate and spatial scale was lacking. This study aimed to synthesize all available $S Y$-measurements in Europe and to provide a first analysis of the collected data.

The data considered in this study were collected under widely varying conditions using different methods. Although the potential sources of error on $S Y$-measurements are well known, the uncertainty on the individual $S Y$-observations could not be assessed because this requires detailed information on the measuring and calculation method which is mostly unknown and rarely reported. Methods and criteria that allow a rough assessment of the involved uncertainty on $S Y$-measurements based on generally available data would be of great 
value, since these would allow to better assess the reliability of $S Y$-measurements conducted in the past.

Despite potentially large uncertainties on several $S Y$-observations, important regional differences in $S Y$ can be noted. Whereas most catchments in northern, western and central Europe are characterized by relatively low $S Y$-values (ca. $50 \%$ of the $S Y<40 \mathrm{t} \mathrm{km}^{-2} \mathrm{y}^{-1}$ and ca. $80 \%$ of the data $<200 \mathrm{t} \mathrm{km}^{-2} \mathrm{y}^{-1}$ ), Mediterranean and Mountainous regions generally have higher $S Y$-values (around $85 \%$ of the $S Y$-data $>40 \mathrm{t} \mathrm{km}^{-2} \mathrm{y}^{-1}$ and more than $50 \%$ of the data $>$ $200 \mathrm{t} \mathrm{km}^{-2} \mathrm{y}^{-1}$ ). As these differences are based on large numbers of observation, they cannot only be attributed to uncertainties on the available data but must be the result of regional variation of the controlling factors of $S Y$ and potentially of different dominant erosion processes.

Based on the current analyses, the individual importance of the various potential controlling factors could not be determined. Subdividing the data according to topographic zone and especially according to climatic region revealed some differences, but the variability of $S Y$ within each region or zone remained very large. This indicates that other factors probably play a larger role at a regional scale. Moreover, important auto-correlations exist between factors that potentially explain the observed $S Y$-differences, which also impede a clear interpretation. Furthermore, calculated $S Y-A$ relationships explained little of the observed variation, are region-specific and scale-dependent.

These findings confirm earlier studies indicating that the relationship between SY, spatial scale and other controlling factors is often complex and non-linear. Hence, $S Y$ - $A$ relationships are an inadequate tool to predict $S Y$ at subcontinental scale, as they do not allow to identify the major controlling factor and as they are subjected to large uncertainties. While, sediment fluxes of large river systems at a global scale were found to be mainly controlled by climate, relief and catchment area (e.g. Syvitski et al., 2005; Syvistki and Milliman, 2007), the 
importance of these factors could not clearly be identified in this study. Future research attempting to predict catchment $S Y$ at a regional scale should therefore aim to improve our understanding of the controlling factors and processes of $S Y$ and assess how these vary with spatial scale. Modelling studies and statistical analyses of $S Y$ already improved our understanding considerably. However, their results are either only valid for specific regions (e.g. Van Rompaey et al., 2001; de Vente et al., 2005; de Vente et al., 2006) or focus mainly on larger river systems (e.g. Delmas et al., 2009). Models aiming to predict $S Y$ for different regions and catchment scales face the difficulty of having to consider all relevant erosion and sediment deposition processes, while keeping input data requirements at a feasible level (e.g. Merrit et al., 2003; de Vente et al., 2008).

\section{Acknowledgments}

The research described in this paper was conducted within the framework of the EC-DG RTD- 6th Framework Research Programme (sub-priority 1.1.6.3) - Research on Desertification- project DESIRE (037046): Desertification Mitigation and Remediation of land - a global approach for local solutions. M. Vanmaercke received grant-aided support from the Research Foundation - Flanders (FWO), Belgium. The authors wish to thank all researchers and institutes who provided data, publications or additional information on the sediment yield and soil loss rate measurements discussed in this study. This manuscript further benefited significantly from the constructive comments by Prof. Des Walling and an anonymous reviewer.

\section{References}

Alvera, B., García-Ruiz, J.M., 2000. Variability of Sediment Yield from a High Mountain Catchment, Central Spanish Pyrenees. Artic, Antartic and Alpine Research 32, 478484.

Asselman, N., 2000. Fitting and interpretation of sediment rating curves. Journal of 
Hydrology 234, 228-248.

Avendaño Salas, C., Cobo Rayán, R., 1997. Metodología para estimar la erosion de cuencas fluviales a partir de la batimetría de embalses. In: Ibáñez, J.J., Valero Garcés, B.L. and Machado, C. (Eds.), El paisaje mediterráneo a través del espacio y del tiempo. Implicaciones en la desertificación. Geoforma Ediciones, Logroño, pp. 239-257.

Avendaño Salas, C., Cobo Rayán, R., Gómez Montaña, J., Sanz Montero, E., 1995. Procedimiento para evaluar la degradación específica (erosión) de cuencas de embalses a partir de los sedimientos acumulados en los mismos. Aplicación al estudio de embalses Españoles. Ingeniería Civil 99, 51-58.

Avendaño Salas, C., Sanz Montero, E., Gómez Montaña, J., 1997. Sediment yield at Spanish reservoirs and its relationship with the drainage basin area. Proceedings of the Dixneuvième Congrès des Grands Barrages, Commission Internationale De Grands Barrages, Florence, Italy, pp. 863-874.

Balasch, J.C., Batalla, R.J., Poch, R.M., Vericat, D., 2005. Patterns of suspended sediment transport in two forested Meditterranean mountainous basins, Ribera Salada, Catalan Pre-Pyrenees, NE Spain. In: Batalla, R., Garcia, C. (Eds.), Geomorphological Processes and Human Impacts in River Basins (Proceedings of the International Conference held at Solsona, Catalonia, Spain, May 2004). IAHS Publ. 299, IAHS, Wallingford, United Kingdom, pp. 131-138.

Balasch, J.C., Castelltort, X., Llorens, P., Gallart, F., 1992. Hydrological and sediment dynamics network design in a Mediterranean mountainous area subject to gully erosion. In: Bogen, J., Walling, D., Day, T. (Eds.), Erosion and Sediment Transport Monitoring Programes in River basins (Proceedings of a symposium held at Oslo, Norway, 24-28 August 1992). IAHS Publ. 210, IAHS, Wallingford, United Kingdom, pp. 423-432.

Barlow, D., Thompson, R., 2000. Holocene sediment erosion in Britain calculated from lakebasin studies. In: Foster, I. (Ed.), Tracers in Geomorphology, Wiley, Chichester, pp. $455-472$.

Bathurst, J.C., Moretti, G., El-Hames, A., Moaven-Hashemi, A., Burton, A., 2005. Scenario modelling of basin-scale, shallow landslide sediment yield, Valsassina, Italian Southern Alps. Natural Hazards and Earth System Sciences 5, 189-202.

Batuca, D., Jordaan, J. M, 2000. Silting and Desilting of Reservoirs. A.A.Balkema, Rotterdam, Netherlands, $353 \mathrm{pp}$.

Bauer, L., Tille, W., 1967. Regional differentiations of the suspended sediment transport in Thuringia and their relation to soil erosion. In: Proceedings of the Symposium on River Morphology (General Assembly of Bern, 25 September-7 October 1967). IAHS Publ. 75, IAHS, Gentbrugge, Belgium, pp. 367-377.

Bayer LfU, Bavarian Environment Agency, 2002. Unpublished data.

Bazzofi, P., 1987. Previsione dellinterrimento nei serbatoi artificiali italiani, modello P.I.S.A. Idrotecnica 1, 15-18.

Becvar, M., 2007. Soil erosion and sediment transport in the Czech Part of the Elbe catchment. Proceedings of the COST 634 International Conference on off-site impacts of soil erosion and sediment transport (1-3 October 2007). Czech Technical University in Prague, Faculty of Civil Engineering, Department of Drainage, Irrigation and Landscape Engineering, Prague, Czech Republic, pp. 81-87.

Bednarczyk, T., Madeyski, M., 1996. Erosional processes in small Carpathian watersheds. In: Walling, D., Webb, B (Eds.), Erosion and Sediment Yield: Global and Regional Perspectives (Proceedings of the Exeter Symposium, July 1996). IAHS Publ. 236, IAHS, Wallingford, United Kingdom, pp. 399-404.

Bednarczyk, T., Madeyski, M., 1998. Assessment of suspended load trapped in a small 
reservoir related to the erosion in a loess basin. In: Summer, W., Klaghofer, E., Zhang, W. (Eds.), Modelling Soil Erosion, Sediment Transport and Closely Related Hydrological Processes (Proceedings of a Symposium held in Vienna, Austria, 13-17 July 1998). IAHS Publ. 249, IAHS, Wallingford, United Kingdom, pp. 241-247.

Beyer Portner, N., 1998. Erosion des bassins versants alpins par ruissellement de surface, Communication 6, Laboratoire de Constructions Hydrauliques, Ecole Polytechnique Fédérale de Lausanne, Lausanne, Switzerland, 340 pp.

Beylich, A.A., Gintz, D., 2004. Effects of high-magnitude/low-frequency fluvial events generated by intense snowmelt or heavy rainfall in arctic periglacial environments in northern Swedish Lapland and northern Siberia. Geografiska Annaler 86A, 11-29.

Beylich, A.A., Kneisel, C., 2009. Sediment Budget and Relief Development in Hrafndalur, Subarctic Oceanic Eastern Iceland. Arctic, Antarctic, and Alpine Research 41, 3-17.

Beylich, A.A., Sandberg, O., Molau, U., Wache, S., 2006. Intensity and spatio-temporal variability of fluvial sediment transfers in an Arctic-oceanic periglacial environment in northernmost Swedish Lapland, Latnjavagge catchment. Geomorphology 80, 114-130.

Blanc, X., Pinteur, F., Sanchis, T., 1989. Conséquences de lenfoncement du lit de lArve sur les berges et les ouvrages Bilan général des transports solides sur le cours deau. La Houille Blanche 3/4, 226-230.

Blinkov, I., 1998. Influence of the rains on the intensity of soil erosion in the Bregalnica watershed up to the profile "Kalimanci Dam", PhD thesis, Faculty of Forestry, Ss. Cyril and Methodius University, Skopje, Macedonia, $127 \mathrm{pp}$.

Boardman, J., Poesen, J., 2006. Soil Erosion in Europe, John Wiley and Sons Ltd., Chichester, England, 855 pp.

Bogardi, J., 1957. Summary of the measurements made in Hungary of sediment transportation, with special reference to their quantitative bearings on erosion. In: Proceedings of the General Assemby of Toronto (3-14 September 1957). IAHS Publ. 43, IAHS, Gentbrugge, Belgium, pp. 277-285.

Bogardi, I., Fogel, M., Duckstein, L., Bardossy, A., 1983. Estimation of sediment loading into Agricultural reservoirs with scarce data. In: Plate, E., Buras, N. (Eds.), Scientific Procedures Applied to the Planning, Design and Management of Water Resources Sytems (Proceedings of the Hamburg Symposium, August 1983). IAHS Publ. 147, IAHS, Wallingford, United Kingdom, pp. 87-98.

Bogen, J., 1995. Sediment Transport and Deposition in Mountain Rivers, In: Foster, I., Gurnell, A., Webb, B. (Eds.), Sediment and Water Quality in River Catchments, John Wiley and Sons Ltd., Chichester, United Kingdom, pp. 437-451.

Bogen, J., 1996. Erosion and sediment yield in Norwegian rivers. In: Walling, D., Webb, B. (Eds.), Erosion and Sediment Yield: Global and Regional Perspectives (Proceedings of the Exeter Symposium, July 1996). IAHS Publ. 236, IAHS, Wallingford, United Kingdom, pp. 73-84.

Bogen, J., Bønsnes, T.E., 2003. Erosion and sediment transport in High Arctic rivers, Svalbard. Polar Research 22, 175-189.

Bogen, J., Bønsnes, T.E., 2005. The impact of hydropower development on the sediment budget of the River Beiarelva, Norway. In: Horowitz, A., Walling, D. (Eds.), Sediment Budgets 2 (Proceedings of symposium S1 held during the Seventh IAHS Scientific Assembly at Foz do Iguaçu, Brazil, April 2005). IAHS Publ. 292, IAHS, Wallingford, United Kingdom, pp. 214-222.

Boix-Fayos, C., Barberá, G.G., López-Bermúdez, F., Castillo, V.M., 2007. Effects of check dams, reforestation and land-use changes on river channel morphology: Case study of the Rogativa catchment, Murcia, Spain. Geomorphology 91, 103-123.

Boix-Fayos, C., de Vente, J., Martínez-Mena, M., Barberá, G.G., Castillo, V., 2008. The 
impact of land use change and check-dams on catchment sediment yield. Hydrological Processes 22, 4922-4935.

Bollinne, A., 1982. Etude et prévision de l'érosion des sols limoneux cultivés en moyenne Belgique, PhD thesis, Faculty of Sciences, Geography, Université de Liége, Liége, Belgium, 356 pp.

Braski, J., Banasik, K., 1996. Sediment yields and denudation rates in Poland. In: Walling, D., Webb, B. (Eds.), Erosion and Sediment Yield: Global and Regional Perspectives (Proceedings of the Exeter Symposium, July 1996). IAHS Publ. 236, IAHS, Wallingford, United Kingdom, pp. 133-138.

Bredahl, L., Sousal, A., 2006. European River Catchments Version 1.01: Methodology and Overview. European Environment Agency, Available online: http://www.eea.europa.eu/data-and-maps/data/european-river-catchments (visited: 0505-2010).

Bronsdon, R.K., Naden, P.S., 2000. Suspended sediment in the Rivers Tweed and Teviot. The Science of the Total Environment 251/252, 95-113.

Bruijnzeel, L.A., 2004. Hydrological functions of tropical forests: not seeing the soil for the trees? Agriculture, Ecosystems and Environment 104, 185-228.

Brune, G.M. 1953: Trap efficiency of reservoirs. Transactions of the American Geophysical Union 34, 407-18.

Butcher, D. P., Labadz, J. C., Potter, A. W. R., White, P., 1993. Reservoir Sedimentation Rates in the Southern Pennine Region, UK. In: McManus, J., Duck, R. (Eds.), John Wiley and Sons Ltd., Chichester, United Kingdom, pp. 73-92.

Cadillon, M., Mori, J., Portier, J., Tremea, L., 1981. La retenue du Trapan, Var. Bureau de Recherches Géologiques et Minières, France, pp. 61-69.

Cammeraat, L.H., 2002. A review of two strongly contrasting geomorphological system within the context of scale. Earth Surface Processes and Landforms 27, 1201-1222.

Casalí, J., Gastesi, R., Álvarez Mozos, J., De Santisteban, L. M., Del Valle de Lersundi, J., Giménez, R., Larrañaga, A., Goñi, M., Agirre, U., Campo, M. A., López, J. J., Donézar, M., 2008. Runoff, erosion, and water quality of agricultural watersheds in central Navarre, Spain. Agricultural Water Management 95, 1111-1128.

Cerdan, O., Govers, G., Le Bissonnais, Y., Van Oost, K., Poesen, J., Saby, N., Gobin, A., Vacca, A., Quinton, J., Auerswald, K., Klik, A., Kwaad, F., Raclot, D., Ionita, I., Rejman, J., Rousseva, S., Muxart, T., Roxo, M., Dostal, T., 2010. Rates and spatial variations of soil erosion in Europe: A study based on erosion plot data. Geomorphology 122, 167-177.

Cloetingh, S., Ziegler, P.A., Beekman, F., Andriessen, P.A.M., Matenco, L., Bada, G., Garcia-Castellanos, D., Hardebol, N., Dèzes, P., Sokoutis, D., 2005. Lithospheric memory, state of stress and rheology: neotectonic controls on Europes intraplate continental topography. Quaternary Science Reviews 24, 241-304.

Coynel, A., Schafer, J., Hurtrez, J., Etcheber, H., 2003. Réseau dobservation des transferts sédimentaires dans le Sud-Ouest de la France: Comportement des petits fleuves montagnards des Pyrénées Atlantiques. In: Proceedings of the International conference on Gully Erosion in Mountain Areas, Processes, Measurement, Modelling and Regionalization (15-17 October 2003), Digne-les-Bains, France, pp. 44-49.

Cravero, J.M., Guichon, P., 1989. Exploitation des retenues et transport des sédiments. La Houille Blanche 3-4, 292-295.

Csáfordi, P., Kalicz, P., Gribovszki, Z., Kucsara, M., 2009. Examination of dam induced sedimentation of small reservoir near Brennbergbánya. In: Geophysical Research Abstracts (proceedings of the EGU General Assembly, Vienna, 20-24 April 2009), Vol. 11, EGU2009-7409-1. 
Csáfordi, P., Kalicz, P., Gribovszki, Z., Kucsara, M., 2008. Examination of sedimentation of small reservoir near Brennbergbánya. In: Proceedings of the international scientific conference „Forest constructions in the country and their recreational use” (Zvolen, 16 oct 2008), Technical University in Zvolen, Slovak Republic, pp. 25-31.

Cyberski, J., 1973. Accumulation of Debris in Water Storage Reservoirs of Central Europe. American Geophysical Union Monograph 17, 359-363.

de Araújo, J.C., Knight, D.W., 2005. A review of the measurement of sediment yield in different scales. Engenharia Civil 58, 257-265.

De Boer, D., Crosby, G., 1996. Specific sediment yield and drainage basin scale. In: Walling, D., Webb, B. (Eds.), Erosion and Sediment Yield: Global and Regional Perspectives (Proceedings of the Exeter Symposium, July 1996). IAHS Publ. 236, IAHS, Wallingford, United Kingdom, pp. 333-338.

De Casa, G., Giglio, G., 1981. Contribution to the study of the correlation between sediment transport and weathering of the formations in the Arno River Basin. In: Erosion and sediment transport measurement (Proceedings of the Florence Symposium, June 1981), part 2: late Papers, Poster Session. pp. 249-256.

Dedkov, A., Gusarov, A.V., 2006. Suspended sediment yield from continents into the World Ocean: spatial and temporal changeability. In: Rowan, J., Duck, J., Werritty, A. (Eds.), Sediment Dynamics and the Hydromorphology of Fluvial Systems (Proceedings of a symposium held in Dundee, UK, July 2006). IAHS Publ. 306, IAHS, Wallingford, United Kingdom, pp. 3-11.

Dedkov, A.P., Moszherin, V.I., 1992. Erosion and sediment yield in mountain regions of the World. In: Walling, D., Davies, R., Hasholt, B. (Eds.), Erosion, Debris Flow and Environment in Mountain Regions (Proceedings of the Chengdu Symposium, July 1992). IAHS Publ. 209, IAHS, Wallingford, United Kingdom, pp. 29-36.

Delmas, M., Cerdan, O., Mouchel, J.-M., Garcin, M., 2009. A method for developing a largescale sediment yield index for European river basins. Journal of Soils and Sediments 9, 613-626.

Dendy, F., Bolton, G., 1976. Sediment yield-runoff drainage area relationships in the United States. Journal of Soil and Water Conservation 31, 264-266.

Descroix, L., 1994. l' Erosion actuelle dans la partie occidentale des Alpes du Sud, PhD thesis, l'Université Lumiére Lyon II, Lyon, France, 337 pp.

de Vente, J., Poesen, J., 2005. Predicting soil erosion and sediment yield at the basin scale: Scale issues and semi-quantitative models. Earth-Science Reviews 71, 95-125.

de Vente, J., Poesen, J., Arabkhedri, M., Verstraeten, G., 2007. The sediment delivery problem revisited. Progress in Physical Geography 31, 155-178.

de Vente, J., Poesen, J., Bazzoffi, P., Van Rompaey, A., Verstraeten, G., 2006. Predicting catchment sediment yield in Mediterranean environments: the importance of sediment sources and connectivity in Italian drainage basins. Earth Surface Processes and Landforms 31, 1017-1034.

de Vente, J., Poesen, J., Verstraeten, G., 2005. The application of semi-quantitative methods and reservoir sedimentation rates for the prediction of basin sediment yield in Spain. Journal of Hydrology 305, 63-86.

de Vente, J., Poesen, J., Verstraeten, G., Van Rompaey, A., Govers, G., 2008. Spatially distributed modelling of soil erosion and sediment yield at regional scales in Spain. Global and Planetary Change 60, 393-415.

Diaconu, C., 1969. Résultats de l'étude de l'écoulement des alluvions en suspension des rivières de la Roumanie. Bulletin of the International Association of Scientific Hydrology 14, 51-89.

Dimitrov, P., Solakov, D., Peychev, V., Dimitrov, D., 2003. The source provinces in the black 
sea. Oceanology 5, 29-35.

Dostál, T., Janecek, M., Kliment, Z., Krása, J., Langhammer, J., Váška, J., Vrana, K., 2006. Czech Republic. In: Boardman, J., Poesen, J. (Eds.), Soil Erosion in Europe, John Wiley and Sons, Ltd., Chichester, United Kingdom, pp. 107-116.

Duijsings, J.J.H.M., 1986. Seasonal variation in the sediment delivery ratio of a forested drainage basin in Luxembourg. In: Hadley, R. (Ed.), Drainage basin delivery (Proceeding of a symposium held in Albuquerque, New Mexico, USA, 4-8 August 1986), IAHS Publ. 159, IAHS, Wallingford, United Kingdom, pp. 153-164.

EC, 2002. Towards a thematic strategy for soil protection. Communication from the commission to the council, the European parliament, the economic and social committe and the committee of regions, Commission of the European Communities, Brussels, Belgium, 35 pp.

EIE (Elektrik Isleri Etüt Idaresi Genel Müdürlügü), 2005. Unpublished sediment yield data. Einsele, G., Hinderer, M., 1997. Terrestrial sediment yield and the lifetimes of reservoirs, lakes, and larger basins. Geologische Rundschau 86, 288-310.

Esteves, J.G., Ludwig, W., 2003. Transfert de matière en suspension et de carbone particulaire dans le bassin versant de la Têt, Sud de la France. In : Servat, E., Najem, W., Leduc, C., Shakeel, A. (Eds.), Hydrology of the Mediterranean and Semiarid Regions (Proceedings of an international symposium held at Montpellier, April 2003). IAHS Publ. 278, IAHS, Wallingford, United Kingdom, pp. 442-447.

Evans, D.J., Gibson, C.E., Rossell, R. S., 2006. Sediment loads and sources in heavily modified Irish catchments: A move towards informed management strategies. Geomorphology 79, 93-113.

Evans, M., Warburton, J., 2005. Sediment budget for an eroding peat-moorland catchment in northern England. Earth Surface Processes and Landforms 30, 557-577.

FAO, 2008. AQUASTAT: Global River Sediment Yields Database, FAO Land Water Development Division. Available online: http://www.fao.org/nr/water/aquastat/sediment/index.asp (consulted, 13 July 2010).

Fauroux, G., 1981. Le délimonage des eaux de la Durance dans le bassin de Cadarache. Bureau de Recherches Géologiques et Minières, France, pp. 125-136.

Ferguson, R., 1986. River Loads Underestimated by Rating Curves. Water Resources Research 22, 74-76.

Ferro, V., Di Stefano, C., Minacapilli, M., Santoro, M., 2003. Calibrating the SEDD model for Sicilian ungauged basins. In: De Boer, D., Froehlich, W., Mizuyama, T., Pietroniro, A. (Eds.), Erosion Prediction in Ungauged Basins: Integrating Methods and Techniques (Proceedings of symposium HS01 held during IUGG2003 at Sapporo, July 2003). IAHS Publ. 279, IAHS, Wallingford, United Kingdom, pp. 151-161.

Finish Environment Institute, 2008. Unpublished data.

Flügel, W.A., 1982. Untersuchungen zum mineralischen Feststoffaustrag eines Lösseinzugsgebietes am Beispiel der Elsenz, Kleiner Odenwald. Zeitschrift für Geomorphologie Suppl. Bd. 4, 103-120.

Foster, I.D.L., Lees, J.A., 1999. Changing headwater suspended sediment yields in the LOIS catchments over the last century: a paleolimnological approach. Hydrological Processes 13, 1137-1153.

Fournier, F., 1969. Transports solides effectués par les cours deau. Bulletin of the International Association of Scientific Hydrology 14(3), 7-49.

FOWG, Federal Office for Water and Geology. 2008. Unpublished data.

Froehlich, W., 1986. Sediment delivery model for the Homerka drainage basin. In: Hadley, R. (Ed.), Drainage basin delivery (Proceeding of a symposium held in Albuquerque, New Mexico, USA, 4-8 August 1986), IAHS Publ. 159, IAHS, Wallingford, United 
Kingdom, pp. 403-412.

Froehlich, W., 1975. The dynamics of fluvial transport in the Kamienica Nawojowska. Prace Geograficzne 114, 122 (in Polish).

Froehlich, W., Walling, D., 2005. Using environmental radionuclides to elucidate sediment sources within a small drainage basin in the Polish Flysch Carpathians. In: Walling, D., Horowitz, A. (Eds.), Sediment Budgets 1 (roceedings of symposium S1 held during the Seventh IAHS Scientific Assembly at Foz do Iguaçu, Brazil, April 2005). IAHS Publ. 291, IAHS, Wallingford, pp. 102-112.

Frosini, P., 1948. Discharge measurements of suspended load in the Reno an Tevere rivers and other studies on the suspended load in the streams. Proceedings of the Assemblée Générale d'Oslo (19-28 Août 1948), IAHS Publ. 29, IAHS, Louvain, Belgium, pp. 269-274.

García-Ruiz, J.M., Regüés, D., Alvera, B., Lana-Renault, N., Serrano-Muela, P., NadalRomero, E., Navas, A., Latron, J., Martí-Bono, C., Arnáez, J., 2008. Flood generation and sediment transport in experimental catchments affected by land use changes in the central Pyrenees. Journal of Hydrology 356, 245-260.

Gazzolo, T., Bassi, G., 1960. Contribution a létude du dégré dérosion des sols constituant les bassins versant des cours d'eau Italiens. Proceedings of the General Assembly of Helsinki (25/7 - 6/8 1960). IAHS Publ. 53, IAHS, Gentbrugge, Belgium, pp. 112-134. Gergov, G., 1996. Suspended sediment load of Bulgarian rivers. Geojournal 40, 387-396.

Gonzalez-Hidalgo, J.C., Batalla, R.J., Cerdà, A., De Luis, M., 2009. Contribution of the largest events to suspended sediment transport across the USA. Land Degradation and Development 21, 83-91.

Grauso, S., Pagano, A., Fattoruso, G., De Bonis, P., Onori, F., Regina, P., Tebano, C., 2008. Relations between climatic-geomorphological parameters and sediment yield in a mediterranean semi-arid area, Sicily, southern Italy. Environmental Geology 54, 219234.

Gray, J., Gartner, J., 2010. Overview of selected surrogate technologies for high-temporal resolution suspended sediment monitoring. Proceedings of the 2nd Joint Federal Interagency Conference (June 27 - July 1, 2010), Las Vegas, NV, pp. 207.

Gray, J., Stewart, D., McFaul, E., Laurent, K., Schwarz, G., Bernard, J., Stinson, J., Jonas, M., Webb, J., Randle, T., 2010. Development of a national, dynamic reservoir sedimentation database. Proceedings of the 2nd Joint Federal Interagency Conference (June 27 - July 1, 2010), Las Vegas, NV, pp. 172.

Grazhdani, S., 2006. Albania. In: Boardman, J., Poesen, J. (Eds.), Soil Erosion in Europe, John Wiley and Sons Ltd., Chichester, United Kingdom, pp. 263-270.

Gögüs, M., Yener, A., 1997. Estimation of sediment yield rates of reservoirs in Turkey. Proceedings of the dix-neuvième Congrès des Grands Barrages, Commision Internationale des Grands Barrages, Florence, Italy, pp.1265-1276.

Habersack, H. M., 1996. Lack and surplus of sediments being transported by river systems. In: Walling, D., Webb, B. (Eds.), Erosion and Sediment Yield: Global and Regional Perspectives (Proceedings of the Exeter Symposium, July 1996). IAHS Publ. 236, IAHS, Wallingford, United Kingdom, pp. 565-574.

Haigh, M. J., Jansky, L., Hellin, J., 2004. Headwater deforestation: a challenge for environmental management. Global Environmental Change 14, 51-61.

Hallet, B., Hunter, L., Bogen, J., 1996. Rates of erosion and sediment evacuation by glaciers: A review of field data and their implications. Global and Planetary Change 12, 213235.

Harlow, A., Webb, B., Walling, D., 2006. Sediment yields in the Exe Basin: a longer-term perspective. In: Rowan, J., Duck, J., Werritty, A. (Eds.), Sediment Dynamics and the 
Hydromorphology of Fluvial Systems (Proceedings of a symposium held in Dundee, UK, July 2006), IAHS Publ. 306, IAHS, Wallingford, United Kingdom, pp. 12-20.

Harrington, S., Harrington, J., 2009. The Particulate Fraction of Nutrients Transported in River Loads in the South Western River Basin District, SWRBD, Ireland. In: Geophysical Research Abstracts (proceedings of the EGU General Assembly, Vienna, 20-24 April 2009), Vol. 11, EGU2009-7409-1.

Hasholt, B., 1991. Influence of erosion on the transport of suspended sediment and Phosphorus. In: Peters, N., Walling, D. (Eds.), Sediment and Stream Water Quality in a Changing Environment: Trends and Explanation (Proceedings of the Vienna Symposium, August 1991). IAHS Publ. 203, IAHS, Wallingford, United Kingdom, pp. 329-338.

Hasholt, B., 1983. Dissolved and particulate load in Danish water courses. In: Webb, B. (Ed.), Dissolved Loads of Rivers and Surface Water Quantity/Quality Relationships (Proceedings of the Hamburg Symposium, August 1983). IAHS Publ. no 141, IAHS, Wallingford, pp.255-264.

Hejduk, L., Hejduk, A., Banasik, K., 2006. Suspended Sediment Transport during Rainfall and Snowmelt-Rainfall Floods in a Small Lowland Catchment, Central Poland. In: Owens, P., Collins, A. (Eds.), Soil Erosion and Sediment Redistribution in River Catchments, CAB International, Wallingford, United Kingdom, pp. 94-100.

Hinderer, M., Einsele, G., 2001. The worlds large lake basins as denudation-accumulation systems and implications for their lifetimes. Journal of Paleolimnology 26, 355-372.

Hodson, A., Gurnell, A., Tranter, M., Bogen, J., Hagen, J.O., Clark, M., 1998. Suspended sediment yield and transfer processes in a small High-Artic glacier basin, Svalbard. Hydrological Processes 12, 73-86.

Holeman, J.N., 1968. The Sediment Yield of Major Rivers of the World. Water Resources Research 4, 737-747.

Huybrechts, W., Verbeelen, D., Van Der Beken, A., 1989. Meting van het sedimenttransport in de Dijle te Korbeek-Dijle. Water 45, 55-59.

Huygens, M., Verhoeven, R., De Sutter, R., 2000. Integrated River management of a small Flemish River catchment. In: Stone, M. (Ed.), The Role of Erosion and Sediment Transport in Nutrient and Contaminent Transfer (Proceedings of a symposium held at Waterloo, Canada, July 2000), IAHS Publ. 263, IAHS, Wallingford, United Kingdom, pp. 191-199.

IAHS, 1974. Gross Sediment Transport into the Oceans, first preliminary ediotion. Technical report, UNESCO, Paris, SC.74/WS/33.

INAG (Instituto Nacional da Agua), 1997. Unpublished data.

Jansen, J., Painter, R., 1974. Predicting sediment yield from climate and topography. Journal of Hydrology 21, 371-380.

Jansky, L., 1992. Sediment accumulation in small water reservoirs utilized for irrigation. In: Younos, T., Diplas, P., Mostaghimi, S. (Eds.), International Symposium on Land Reclamation-Advances in Research and Technology, Nashville, Americian Association of Agricultural Engineers, St. Josephs, MI, pp. 76-82.

Jansson, M. B., 1982. Land erosion by water in different climates, PhD thesis, Uppsala University, Upsala, Sweden, 151 pp.

Jansson, M. B., 1988. A Global Survey of Sediment Yield. Geografiska Annaler 70A, 81-98. Jaoshvili, S., 2002. The rivers of the Black Sea. EEA Technical report 71, European Environmental Agency, $58 \mathrm{pp}$. Available from: http://www.reports.eea.europa.eu/technical_report_2002_71/en.

Jauffret, D., Vérague, J., 1986. Etude quantitative du transport en suspension de deux cours d'eau en milieu granitique tempéré océanique. Rapports scientifiques et techniques no. 
3, CNRS - Centrre de géomorphologie, Caen, France, 50 pp.

Jovanovic, S., Vukcevic, M., 1957. Suspended sediment regimen on some watercourses in Yuguslavia and analysis of erosion processes. In: Proceedings of the General Assemby of Toronto, 3-14 September 1957. Volume I: Land Erosion, Instruments, Precipitations, IAHS, Gentbrugge, Belgium, pp. 337-359.

Kadlec, J., Kliment, Z., Langhammer, J., 2007. Evaluation of the ANNAGNPS and SWAT sediment transport models in the Blšanka Catchment, Czech Republic. Proceedings of the COST 634 International Conference on off-site impacts of soil erosion and sediment transport (1-3 October 2007). Czech Technical University in Prague, Faculty of Civil Engineering, Department of Drainage, Irrigation and Landscape Engineering, Prague, Czech Republic, pp. 145-155.

Kirkby, M. J., 1984. The Hurst effect and its implications for extrapolating processes data. Earth Surface Processes and Landforms 12, 57-67.

Kirkby, M. J., Jones, R. J. A., Irvine, B., Gobin, A, Govers, G., Cerdan, O., Van Rompaey, A. J. J., Le Bissonnais, Y., Daroussin, J., King, D., Montanarella, L., Grimm, M., Vieillefont, V., Puigdefabregas, J., Boer, M., Kosmas, C., Yassoglou, N., Tsara, M., Mantel, S., Van Lynden, G. J., Huting, J., 2004. Pan-European soil erosion risk assessment: The PESERA Map, Version 1 October 2003. Explanation of Special Publication Ispra 2004 no.73 (S.P.I.04.73). European Soil Bureau Research Report no. 16, Luxembourg, EUR 21176, 18 pp. + 1 map.

Korup, O., 2005. Distribution of landslides in southwest New Zealand. Landslides 2, 43-51.

Korup, O., McSaveney, M.J., Davies, T.R.H., 2004. Sediment generation and delivery from large historic landslides in the Southern Alps, New Zealand. Geomorphology 61, 189207.

Kosmas, C., Danalatos, N., Cammeraat, L.H., Chabart, M., Diamantopoulos, J., Farand, R., Gutierrez, L., Jacob, A., Marques, H., Martinez-Fernandez, J., 1997. The effect of land use on runoff and soil erosion rates under Mediterranean conditions. Catena 29, 45-59.

Kostadinov, S., Markovic, S., 1996. Soil erosion and effects of erosion control works in the torrential drainage basins of southeast Serbia. In: Walling, D., Webb, B. (Eds.), Erosion and Sediment Yield: Global and Regional Perspectives (Proceedings of the Exeter Symposium, July 1996). IAHS Publ. 236, IAHS, Wallingford, United Kingdom, pp. 321-332.

Kovalchuk, I.P., Vishnevskiy, V.I., 2004. Investigation of sediment yield of lowland rivers in Ukraine. In: Golosov, V., Belyaev, V., Walling, D. (Eds.), Sediment Transfer through the Fluvial System (Proceedings of the Moscow Symposium, August 2004). IAHS Publ. 288, IAHS, Wallingford, United Kingdom, pp. 130-137.

Krasa, J., Dostal, T., Van Rompaey, A., Vaska, J., Vrana, K., 2005. Reservoirs siltation measurments and sediment transport assessment in the Czech Republic, the Vrchlice catchment study. Catena 64, 348-362.

Labadz, J.C., Butcher, D.P., Potter, A.W.R., 1991. Moorland erosion in the Southern Pennines. Part 1. Research Monograph No. 1, Department of Geographical and Environmental Sciences, Polytechnic of Huddersfield, Huddersfield, United Kingdom, $53 \mathrm{pp}$.

Lajczak, A., 2003. Contemporary transport of suspended material and its deposition in the Vistula River, Poland. Hydrobiologia 494, 43-49.

Lajczak, A., 1996. Reservoir sedimentation problems in the Vistula River basin, Poland. In: Walling, D., Webb, B. (Eds.), Erosion and Sediment Yield: Global and Regional Perspectives (Proceedings of the Exeter Symposium, July 1996). IAHS Publ. 236, IAHS, Wallingford, United Kingdom, pp. 501-511.

Lamalle, C., Petit, F., Koch, G., Hurtgen, C., Pissart, A., 1989. Les transports en suspension et 
en solution dans la Burdinale, affluent de principale de la Méhaigne. Bulletin de la Société Géographique de Liège 25, 39-51.

Laubel, A., Svendsen, L.M., Kronvang, B., Larsen, S. E., 1999. Bank erosion in a Danish lowland stream system. Hydrobiologia 410, 279-285.

Lawler, D.M., 1994. Recent changes in rates of suspended sediment transport in the Jökulsá á Sólheimasandi glacial river, southern Iceland. In: Olive, L., Loughran, R., Kesby, J. (Eds.), Variability in Stream Erosion and Sediment Transport (Proceedings of the Canberra Symposium, December 1994). IAHS Publ. 224, IAHS, Wallingford, United Kingdom, pp. 343-350.

Lefrançois, J., Grimaldi, C., Gascuel-Odoux, C., Gilliet, N., 2007. Suspended sediment and discharge relationships to identify bank degradation as a main sediment source on small agricultural catchments. Hydrological Processes 21, 2923-2933.

Lemin, G., Koch, G., Hurtgen, C., Pissart, A., 1987. Les transports en suspension de la Meuse, l'Ourthe et la Höegne. Bulletin de la Société Géographique de Liège 22-23, 39-61.

Lepistö, A., Granlund, K., Kortelainen, P., Räike, A., 2006. Nitrogen in river basins: Sources, retention in the surface waters and peatlands, and flux to estuaries in Finland. Science of the Total Environment 365, 238-259.

Llovet, J., Bautista, S., Giovanardi, F., Vallejo, V., 1998. Sediment production in burned catchments of eastern spain. Proceedings of the 23th General Assembly of the European Geophysical Society (EGU), Nice (20-24 April 1998), France, HSC1:03.

Mano, V., Moatar, F., Coynel, A., Etcheber, H., Ludwig, W., Meybeck, M., Nemery, J., Poirel, A., Blanc, G., Schafer, J., 2006. Space and time variability of suspended particulate matter (SPM) transport in 32 French rivers (100 to $100000 \mathrm{~km}^{2}$; daily to yearly). Sediment Dynamics and the Hydromorphology of Fluvial Systems ICCE IAHS International Symposium, 3rd-7th July 2006, Dundee, Scotland, Poster Report Booklet, pp. 29-37.

Martin, C., Allée, P., Béguin, E., Kuzucuoglu, C., Levant, M., 1997. Mesure de l'érosion mécanique des sols après un incendie de forêt dans le massif des Maures. Géomorphologie: relief, processus, environment 2, 133-142.

Martínez-Carreras, N., Udelhoven, T., Krein, A., Gallart, F., Iffly, J.F., Ziebel, J.F., Hoffmann, L., Pfister, L., Walling, D., 2010. The use of sediment colour measured by diffuse reflectance spectrometry to determine sediment sources: Application to the Attert River catchment, Luxembourg. Journal of Hydrology 382, 49-63.

McManus, J., Duck, R.W., 1996. Regional variations of fluvial sediment yield in eastern Scotland. In: Walling, D., Webb, B. (Eds.), Erosion and Sediment Yield: Global and Regional Perspectives (Proceedings of the Exeter Symposium, July 1996). IAHS Publ. 236, IAHS, Wallingford, United Kingdom, pp. 157-161.

MEA, 2005. Ecosystems and Human Well-Being: Desertification Synthesis, World Resources Institute, Washington, DC, $155 \mathrm{pp}$. Available online: http://www.millenniumassessment.org/documents/document.356.aspx.pdf

Merritt, W., Letcher, R., Jakeman, A., 2003. A review of erosion and sediment transport models. Environmental Modelling and Software 18, 761-799.

Metzger, M., Bunce, R., Jongman, R., Mücher, C., Watkins, J., 2005. A climatic stratification of the environment of Europe. Global Ecology and Biogeography 14, 549-563.

Meybeck, M., Laroche, L., Dürr, H., Syvitski, J., 2003. Global variability of daily total suspended solids and their fluxes in rivers. Global and Planetary Change 39, 65-93.

Meybeck, M., Ragu, A., 1995. River discharges to the oceans: an assessment of suspended solids, major ions and nutrients, U. N. Environment Programme (UNEP), Nairobi, Kenya, 240 pp. 
Milliman, J.D., 2001. Delivery and fate of fluvial water and sediment to the sea: a marine geologist's view of European rivers. Scientia Marina 65, 121-132.

Milliman, J.D., Meade, R., 1983. World wide delivery of river sediment to the oceans. The Journal of Geology 91, 1-21.

Milliman, J.D., Rutkowski, C.M., Meybeck, M., 1995. River discharge to the sea. A global river index (GLORI). International Geosphere Biosphere Program (IBGP): LandOcean Interactions in the Coastal Zone (LOICZ), The Netherlands, 138 pp.

Milliman, J.D., Syvitski, J.P.M., 1992. Geomorphic/Tectonic Control of Sediment Discharge to the Ocean: The Importance of Small Mountainous Rivers. The Journal of Geology $100,525-544$.

Moatar, F., Person, G., Meybeck, M., Coynel, A., Etcheber, H., Crouzet, P., 2006. The influence of contrasting suspended particulate matter transport regimes on the bias and precision of flux estimates. Science of the Total Environment 370, 515-531.

Montgomery, D.R., Brandon, M.T., 2002. Topographic controls on erosion rates in tectonically active mountain ranges. Earth and Planetary Science Letters 201, 481489.

Mücher, C., Wascher, D., Klijn, J., Koomen, A., Jongman, R., 2006. A new European Landscape Map as an integrative framework for landscape character assessment. In: Bunceand, R., Jongman, R. (Eds.), Landscape Ecology in the Mediterranean: inside and outside approaches (Proceedings of the European IALE Conference 29 March - 2 April 2005), Faro, Portugal., pp. 233-243.

Nadal-Romero, E., Regüés, D., Latron, J., Lana-Renault, N., Serrano-Muela, P., Martí-Bono, C., 2007. Badland areas: the main suspended sediment source in Central Spanish Pyrenees. Proceedings of the COST 634 International Conference on off-site impacts of soil erosion and sediment transport (1-3 October 2007). Czech Technical University in Prague, Faculty of Civil Engineering, Department of Drainage, Irrigation and Landscape Engineering, Prague, Czech Republic, pp.115-123.

Nadal-Romero, E., Martínez-Murillo, J.-F., Vanmaercke, M., Poesen, J., 2011. Scaledependency of sediment yield from badland areas in Mediterranean environments. Progress in Physical Geography, in press.

Niemi, J., Heinonen, P., Mitikka, S., Vuoristo, H., Pietiläinen, O.-P., Puupponen, M., Rönkä, E., 2001. The Finnish Eurowaternet, with information about Finnish water resources and monitoring strategies. The Finnish Environment, 445, Finnish Environment Institute, Helsinki, 64 pp.

Nippes, K.-R., 1971. A new method of computation of the suspended sediment load. In: Mathematical Models in Hydrology (Proceedings of a symposium held at Warshaw, july 1971), IAHS Publ. 101, IAHS/UNESCO, pp. 659-666.

Old, G.H., Lawler, D.M., Snorrason, Á., 2005. Discharge and suspended sediment dynamics during two jökulhlaups in the Skaftá river, Iceland. Earth Surface Processes and Landforms 30, 1441-1460.

Olivry, J.C., Hoorelbeck, J., 1989. Erodibilité des terres noires de la vallée du Buëch, France, Alpes du Sud. ORSTOM 25, 95-110.

Owens, P.N., Batalla, R.J., 2003. A first attempt to approximate Europes sediment budget, SedNet, $7 \mathrm{pp}$.

Owens, P.N., Batalla, R.J., Collins, A.J., Gomez, B., Hicks, D.M., Horowitz, A.J., Kondolf, G.M., Marden, M., Page, M.J., Peacock, D.H., Petticrew, E.L., Salomons, W., Trustrum, N.A., 2005. Fine-grained sediment in River Systems: environmental significance and management issues. River Research and Applications 21, 693-717.

Øygarden, L., Lundekvam, H., Arnoldussen, A. H., Børresen, T., 2006. Norway. In: Boardman, J., Poesen, J. (Eds.), Soil Erosion in Europe, John Wiley and Sons Ltd., 
Chichester, United Kingdom, pp. 3-16.

Pálsson, S., Hardardóttir, J., Vigfússon, G. H., Snorrason, A., 2000. Reassessment of suspended sediment load of river Jökulsá á Dal at Hjardarhagi. Orkustofnun Hydrological Servive, Iceland, OS-2000/070, 31 pp.

Pavanelli, D., Rigotti, M., 2007. Relationship between suspended sediment concentration and total Nitrogen, and comparison among basins for some Apennine Rivers. Proceedings of the COST 634 International Conference on off-site impacts of soil erosion and sediment transport (1-3 October 2007). Czech Technical University in Prague, Faculty of Civil Engineering, Department of Drainage, Irrigation and Landscape Engineering, Prague, Czech Republic, pp. 167-176.

Petkovic, S., Dragovic, N., Markovic, S., 1999. Erosion and sedimentation problems in Serbia. Hydrological Sciences Journal 44, 63-77.

Phillips, J., Webb, B., Walling, D., Leeks, G., 1999. Estimating the suspended sediment loads of rivers in the LOIS study area using infrequent samples. Hydrological processes 13, 1035-1050.

Poesen, J., Vanwalleghem, T., de Vente, J., Knapen, A., Verstraeten, G., Martínez-Casasnova, J., 2006. Gully erosion in Europe. In: Boardman, J., Poesen, J. (Eds.), Soil Erosion in Europe, John Wiley and Sons Ltd., Chichester, United Kingdom, pp. 515-536.

Pont, D., Simonnet, J.-P., Walter, A., 2002. Medium-term Changes in Suspended Sediment Delivery to the Ocean: Consequences of Catchment Heterogeneity and River Management (Rhone River, France). Estuarine. Coastal and Shelf Science 54, 1-18.

Porto, P., Walling, D., Callegari, G., 2004. Validating the use of Caesium-137 measurements to estimate erosion rates in three small catchments in Southern Italy. In: Golosov, V., Belyaev, V., Walling, D. (Eds.), Sediment Transfer through the Fluvial System (Proceedings of the Moscow Symposium, August 2004). IAHS Publ. 288, IAHS, Wallingford, United Kingdom, pp. 78-83.

Poulos, S., Chronis, G.T., Collins, M., Lykousis, V., 2000. Thermakaios Gulf Coastal System, NW Aegean Sea: an overview of water/sediment fluxes in relation to air-land-ocean interactions and human activities. Journal of Marine Systems 25, 47-76.

Pustelnikovas, O., 1994. Transport and accumulation of sediment and contaminants in the Lagoon of Kursiumarios, Lithuania) and Baltic Sea. Aquatic Ecology 28, 405-411.

Puustinen, M., Tattari, S., Koskiaho, J., Linjama, J., 2007. Influence of seasonal and annual hydrological variations on erosion and phosphorus transport from arable areas in Finland. Soil. Tillage Research 93, 44-55.

Rãdoane, M., Rãdoane, N., 2005. Dams, sediment sources and reservoir silting in Romania. Geomorphology 71, 112-125.

Räike, A., Pietiläinen, O.-P., Rekolainen, S., Kauppila, P., Pitkänen, H., Niemi, J., Raateland, A., Vuorenmaa, J., 2003. Trends of phosphorus, nitrogen and chlorophyll a concentrations in Finnish rivers and lakes in 1975-2000. The Science of the Total Environment 310, 47-59.

Regües, D., Soler, M., Gallart, F., 2003. Temporal Patterns of Sediment Yield and Transport from Mountain Mediterranean Badlands, Vallcebre, Eastern Pyrenees. Poster at the International Conference on Soil Erosion and Sediment Redistribution (9-11 September 2003), Silsoe, United Kingdom.

Rekolainen, S., Ekholm, P., Heathwaite, L., Lehtoranta, J., Uusitalo, R., 2006. Off-site impacts of Erosion: Eutrophication as an Example. In: Boardman, J., Poesen, J. (Eds.), Soil Erosion in Europe, John Wiley and Sons Ltd., Chichester, United Kingdom, pp. 775-789.

RIKZ, IGN, EADS, BRGM, UAB, IFEN, EUCC, 2004. Living with coastal erosion in Europe: Sediment and Space for Sustainability. PART II - Maps and statistics, 
Eurosion, (Available online: http://www.eurosion.org/reports-online/part2.pdf).

Rojek, W., Zmuda, R. 1992. Intensity of water erosion in the basins of the 'Jastrzab' and Wilkanowski stream in East Sudety. In: Mazur, Z. (Ed.), Soil Erosion and its protection, AR Lublin Press, Lublin, Poland, pp. 117-128 (in Polish).

Rovira, A., Batalla, R. J., 2006. Temporal distribution of suspended sediment transport in a Mediterranean basin: the Lower Tordera (NE SPAIN). Geomorphology 79, 58-71.

Rovira, A., Batalla, R. J., Sala, M., 2005. Fluvial sediment budget of a Mediterranean river: the lower Tordera, Catalan Coastal Ranges (NE Spain). Catena 60, 19-42.

Sande Fouz, P., Vidal Vázquez, E., Mirás Avalos, J.M., 2006. Assessment of soil erosion rates at the field and catchment scales in Galicia (Spain) from 1999 to 2004.

Proceedings of the 14th ISCO Conference: Water Management and Soil Conservation in Semi-Arid Environments (May 14-19, 2006), ISCO, Marrakech, Morocco, CDRom.

Savey, P., Deléglise, R., 1967. Les incidences de l'aménagement du tiers central du BasRhone sur les transports solides par suspension. Proceedings of the Symposium on River Morphology (General Assembly of Bern, 25 Sept. - 7 Oct. 1967). IAHS Publ. 75, IAHS, Gentbrugge, Belgium, pp. 462-476.

Schröder, W., Theune, C., 1984. Feststoffabtrag und Stauraumverlandung in Mitteleuropa. Wasserwirtschaft 74, 374-379.

Schäfer, J., Blanc, G., Lapaquellerie, Y., Maillet, N., Maneux, E., Etcheber, H., 2002. Tenyear observation of the Gironde tributary fluvial system: fluxes of suspended matter, particulate organic carbon and cadmium. Marine Chemistry 79, 229-242.

Sine, L., Agneessens, J., 1978. Etude des débits solides et du phénomène de migration dans une rivière drainant un bassin agricole. Pédologie $28,183-191$.

Sisák, I., Máté, F., Szüics, P., 2007. Sediment and phosphorous loads from three small catchments in the watershed of Lake Balaton. Proceedings of the COST 634 International Conference on off-site impacts of soil erosion and sediment transport (13 October 2007). Czech Technical University in Prague, Faculty of Civil Engineering, Department of Drainage, Irrigation and Landscape Engineering, Prague, Czech Republic, pp. 54.

Skoklevski, Z., Velickov, S., 1995. Total suspended load transport as a natural stochastic process. In: Osterkamp, W. (Ed.), Effects of Scale on Interpretation and Management of Sediment and Water Quality (Proceedings of a Symposium held at Boulder, July 1995). IAHS Publ. 226, IAHS, Wallingford, United Kingdom, pp. 215-221.

Small, I.F., Rowan, J.S., Duck, R.W., 2003. Long-term sediment yield in Crombie Reservoir catchment, Angus, and its regional significance within the Midland Valley of Scotland. Hydrological Sciences 48, 619-635.

SMHI (Swedish Meteorological and Hydrological Institute), 2008. Unpublished data.

Sogon, S., Penven, M., Bonte, P., Muxart, T., 1999. Estimation of sediment yield ans soil loss using suspended sediment load and 137Cs measurements on agricultural land, Brie Plateau, France. Hydrobiologia 410, 251-261.

Soler, M., Latron, J., Gallart, F., 2008. Relationships between suspended sediment concentrations and discharge in two small research basins in a mountainous Mediterranean area, Vallcebre (Eastern Pyrenees). Geomorphology 98, 143-152.

Stanners, D., Bourdeau, P., 1995. Europe's Environment - The Dobris Assessment, European Environment Agency. Available online: http://www.eea.europa.eu/publications/92826-5409-5.

Steegen, A., 2001. Sediment deposition in and export from small agricultural catchments, $\mathrm{PhD}$ thesis, Faculty of Sciences, Geography, K.U.Leuven, Leuven, Belgium, 220 pp.

Steegen, A., Govers, G., 2001. Correction factors for estimating suspended sediment export 
from loess catchments. Earth Surface Processes and Landforms 26, 441-449.

Steegen, A., Govers, G., Nachtergaele, J., Takken, I., Beuselinck, L., Poesen, J., 2000.

Sediment export by water from an agricultural catchment in the Loam Belt of central Belgium. Geomorphology 33, 25-36.

Straumann, R.K., Korup, O., 2005. Quantifying postglacial sediment storage at the mountainbelt scale. Geology 37, 1079-1082.

Syvitski, J.P.M., Milliman, J.D., 2007. Geology, Geography, and Humans Battle for Dominance over the Delivery of Fluvial Sediment to the Coastal Ocean. The Journal of Geology 115, 1-19.

Syvitski, J.P.M., Vörösmarty, C.J., Kettner, A.J., Green, P., 2005. Impact of Humans on the Flux of Terrestrial Sediment to the Global Coastal Ocean. Science 308, 376-380.

Tamburino, V., Barbagallo, S., Vella, P., 1990. Evaluation of sediment deposition in Sicilian artificial reservoirs. In: Sinniger, R., Monbaron, M. (Eds.), Hydrology in Mountainous Regions II: Artificial Reservoirs, Water and Slopes (Proceedings of two Lausanne Symposia, August 1990). IAHS Publ. 194, IAHS, Wallingford, United Kingdom, pp. 107-112.

Tamburino, V., Barbagallo, S., Vella, P., 1989. Indagine sullinterrimento dei serbatoi artificiali siciliana. Ingegneria Agraria 3, 156-164.

Tattari, S., Rekolainen, S., 2006. Finland. In: Boardman, J., Poesen, J. (Eds.), Soil Erosion in Europe, John Wiley and Sons Ltd., Chichester, United Kingdom, pp. 27-32.

Teixeira, E.C., Caliari, P.C., 2005. Estimation of the concentration of suspended solids in rivers from turbidity measurements: error assessment. In: Walling, D., Horowitz, A. (Eds.), Sediment Budgets 1 (Proceedings of symposium S1 held during the Seventh IAHS Scientific Assembly at Foz do Iguaçu, Brazil, April 2005), IAHS Publ. 291, IAHS, Wallingford, United Kingdom, pp. 151-160.

Thodsen, H., Hasholt, B., Perjup, M., 2004. Transport of phosphorus, wash load and suspended sediment in the River Varde $\AA$ in southwest Jutland, Denmark. In: Golosov, V., Belyaev, V., Walling, D. (Eds.), Sediment Transfer through the Fluvial System (Proceedings of the Moscow Symposium, August 2004), IAHS Publ. 288, IAHS, Wallingford, United Kingdom, pp. 466-473.

Tijms, H., 2004. Understanding Probability: Chance Rules in Everyday Life, Cambridge University Press, Cambridge, United Kingdom, 452 pp.

Torri, D., Borselli, L., Guzzetti, F., Calzolari, M. C., Bazzofi, P., Ungaro, F., Bartolini, D., Salvador Sanchis, M. P., 2006. Italy. In: Boardman, J., Poesen, J. (Eds.), Soil Erosion in Europe, John Wiley and Sons Ltd., Chichester, United Kingdom, pp. 245-262.

Trendafilov, A., 1996. Erosion in the Crna River catchment and sedimentation of the Tikvesh reservoir, PhD thesis, Faculty of Forestry, Ss. Cyril and Methodius University, Skopje, Macedonia, 256 pp. (in Macedonian).

Tropeano, D., 1984. Soil Loss and Sediment Yield from a small basin in the langhe area, Piedmont (NW Italy): a first report. Geologia Applicata e Idrogeologica 19, 269-287.

Tschada, H., Hofer, B., 1990. Total solids load from the catchment area of the Kaunertal hydroelectric power station : the results of 25 years of operation. In: Sinniger, R., Monbaron, M. (Eds.), Hydrology in Mountainous Regions II: Artificial Reservoirs, Water and Slopes (Proceedings of two Lausanne Symposia, August 1990). IAHS Publ. 194, IAHS, Wallingford, United Kingdom, pp. 121-128.

Turowski, J., Rickenmann, D., Dadson, J.S., 2010. The partitioning of the total sediment load of a river into suspended load and bedload: A review of empirical data. Sedimentology 57, 1126-1146.

Van Dijk, P.M., Kwaad, F.J.P.M., 1996. Runoff generation and soil erosion in small agricultural catchments with loess-derived soils. Hydrological Processes 10, 1049- 
1059.

Van Hoestenberghe, T., Voet, M., Eylenbosch, J., Cabus, P., 2008. Sedimentexport door onbevaarbare waterlopen in Vlaanderen: Metingen 2003-2007. Vlaamse

Milieumaatschappij, Afdeling Operationeel Waterbeheer, Belgium, D/2008/6871/021, $131 \mathrm{pp}$.

Van Rompaey, A., Bazzoffi, P., Jones, R. J. A., Montanarella, L., 2005. Modelling sediment yields in Italian catchments. Geomorphology 65, 157-169.

Van Rompaey, A., Krasa, J., Dostal, T., Govers, G., 2003. Modelling sediment supply to rivers and reservoirs in Eastern Europe during and after the collectivisation period. Hydrobiologia 494, 169-176.

Van Rompaey, A., Verstraeten, G., Van Oost, K., Govers, G., Poesen, J., 2001. Modelling mean annual sediment yield using a distributed approach. Earth Surface Processes and Landforms 27, 1221-1236.

Vanacker, V., von Blanckenburg, F., Govers, G., Molina, A., Poesen, J., Deckers, J., Kubik, P., 2007. Restoring dense vegetation can slow mountain erosion to near natural benchmark levels. Geology 35, 303-306.

Vanlierde, E., De Schutter, J., Meys, J.F.A., Mostaert, F., Jacobs, P., 2005. Contributions of authigenic iron compounds to fluvial suspended sediment concentrations and fluxes in the Nete sub-basin, Belgium. In: Walling, D., Horowitz, A. (Eds.),Sediment Budgets 1 (Proceedings of symposium S1, held during the Seventh IAHS Scientific Assembly at Foz do Iguaçu, Brazil, April 2005), IAHS Publ. 291, IAHS, Wallingford, United Kingdom, pp. 54-63.

Vanmaercke, M., Poesen, J., Maetens, W., de Vente, J., Verstraeten, G., 2011. Sediment yield as a desertification indicator. Science of the total environment, in press (doi: 10.1016/j.scitotenv.2011.01.034).

Verstraeten, G., Bazzoffi, P., Lajczak, A., Radoane, M., Rey, F., Poesen, J., de Vente, J., 2006. Reservoir and Pond Sedimentation in Europe In: Boardman, J., Poesen, J. (Eds.), Soil Erosion in Europe, John Wiley and Sons Ltd., Chichester, United Kingdom, pp. 759-774.

Verstraeten, G., Poesen, J., 1999. The nature of small-scale flooding, muddy floods and retention pond sedimentation in central Belgium. Geomorphology 29, 275-292.

Verstraeten, G., Poesen, J., 2000. Estimating trap efficiency of small reservoirs and ponds: methods and implications for the assessment of sediment yield. Progress in Physical Geography 24, 219-251.

Verstraeten, G., Poesen, J., 2001. Factors controlling sediment yield from small intensively cultivated catchments in a temperate humid climate. Geomorphology 40, 123-144.

Verstraeten, G., Poesen, J., 2002. Using sediment deposits in small ponds to quantify sediment yield from small catchments: possibilities and limitations. Earth Surface Processes and Landforms 27, 1425-1439.

Verstraten, J.M., 1977. Chemical erosion in a forested watershed in the Oesling, Luxembourg. Earth Surface Processes and Landforms 2, 175-184.

Vivian, H., Thomas, A., 1982. Erosion et Transports Solides dans le Bassin du Haut Drac (en Amont de la Retenue du Sautet), Cemagraf, Grenoble.

Voet, M., 1997. Sedimentafvoeren in kleine stroomgebieden. Water 92, 10-14.

Vörösmarty, C. 2002. Global water assessment and potential contributions from Earth Systems Science. Aquatic Science 64, 328-351.

Vörösmarty, C., Meybeck, M., Fekete, B., Sharma, K., Green, P., Syvitski, J. 2003. Anthropogenic sediment retention: major global impact from registered river impoundments. Global and Planetary Change 39, 169-190.

Vuorenmaa, J., Rekolainen, S., Lepistö, A., Kenttämies, K., Kauppila, P., 2002. Losses of 
Nitrogen and phosphorus from agricultural and forest areas in Finland during the 1980s and 1990s. Environmental Monitoring and Assessment 76, 213-248.

Walling, D., 1983. The sediment delivery problem. Journal of Hydrology 65, 209-237.

Walling, D., Kleo, A., 1979. Sediment yields of rivers in areas of low precipitation: a global view. In: Hydrology of Areas of Low Precipitation, Proceedings of a symposium held during the XVII Assembly of the International Union of Geodesy and Geophysics at Canberra, December 1979. pp. 479-493.

Walling, D., 2006. Human impact on land-ocean sediment transfer by the worlds rivers. Geomorphology 79, 192-216.

Walling, D.., Webb, B.W., 1983. Patterns of Sediment Yield. In: Gregory, K. (Ed.), Background to Paleohydrology, Wiley, New York, USA, pp. 69-100.

Walling, D., Webb, B.W., 1996. Erosion and sediment yield: a global overview. In: Walling, D., Webb, B (Eds.), Erosion and Sediment Yield: Global and Regional Perspectives (Proceedings of the Exeter Symposium, July 1996). IAHS Publ. 236, IAHS, Wallingford, United Kingdom, pp. 3-19.

Wass, P.D., Leeks, G.J.L., 1999. Suspended sediment fluxes in the Humber catchment, UK. Hydrological Processes 13, 935-953.

WCD, 2000. Dams and Development. A new framework for decision-making, Earthscan publications Ltd., London, 356 pp. Available online: http://www.dams.org//docs/report/wcdreport.pdf.

Webb, B.W., Phillips, J.M., Walling, D., Littlewood, I.G., Watts, C.D., Leeks, G.J.L., 1997. Load estimation methodologies for British rivers and their relevance to the LOIS RACS(R) programme. Science of The Total Environment 194-195, 379-389.

Weiss, F.H., 1996. Sediment monitoring, long-term loads, balances and management strategies in southern Bavaria. In: Walling, D., Webb, B (Eds.), Erosion and Sediment Yield: Global and Regional Perspectives (Proceedings of the Exeter Symposium, July 1996). IAHS Publ. 236, IAHS, Wallingford, United Kingdom, pp. 575-582.

White, R., 2001. Evacuation of sediments from reservoirs, Thomas Telford Publishing, London, United Kingdom, 280 pp.

Wilson, L., 1977. Sediment yield as a function of climate in United States rivers. In: Erosion and Solid Matter Transport in Inland Waters (Proceedings of a symposium held at Paris, July 1977), IAHS Publ. 122, pp. 82-92.

Wirix, G., Lorent, J., 1966. Regime en lading van de Dender. Acta Geographica Lovaniensia 4, 129-140.

Woodward, J.C., 1995. Patterns of erosion and suspended sediment yield in Mediterranean river basins. In: Foster, I., Gurnell, A., Webb, B. (Eds.), Sediment and Water Quality in River Catchments, John Wiley and Sons Ltd., Chichester, United Kingdom, pp. 365-389.

Zarris, D., Koutsoyiannis, D., 2005. Evaluating sediment yield estimations from large-scale hydrologic systems using the rating curve concept. RMZ - Materials and Geoenvironment 52, 157-159.

Zarris, D., Lykoudi, E., Panagoulia, D., 2007. Sediment Yield estimations in North-Western Greece and analysis with hydrological and geomorphologic factors. In: Bulletin of the Geological Society of Greece vol. 37, Proceedings of the 11th International Congres (Athens, May, 2007), $11 \mathrm{pp}$.

Zmuda, R., 1998. Influence of hydrometeorological factors on intensity of water erosion in the Mielnica stream catchment on Trzebnica Hills area. Bibliotheca Fragmenta Agronomica 4A, 41-63 (in Polish). 


\section{TABLES AND FIGURES}

\section{Tables:}

Table 1: Overview of global inventories of sediment yield data, their total number of entries (\# Entries), the number of entries for Europe and their corresponding range of catchment areas $(A)$.

\begin{tabular}{ccccc}
\hline Reference & $\begin{array}{c}\text { Total \# } \\
\text { Entries }\end{array}$ & $\begin{array}{c}\text { \# Entries } \\
\text { in Europe }\end{array}$ & $\begin{array}{c}\text { Min. A } \\
\left(\mathrm{km}^{2}\right) \text { for } \\
\text { Europe }\end{array}$ & $\begin{array}{c}\text { Max. A } \\
\left(\mathrm{km}^{2}\right) \text { for } \\
\text { Europe }\end{array}$ \\
\hline Holeman, 1968 & 110 & 20 & 1831 & 1350653 \\
Fournier, 1969 & 139 & 93 & 14.8 & 193900 \\
Jansen and Painter, 1974 & 79 & 22 & 5288 & 1350085 \\
Walling and Kleo, 1979 & 1246 & 396 & N.A. & N.A. \\
Walling and Webb, 1983 & $<1500$ & N.A. & $1000-10000^{1}$ \\
GLORI: Meybeck and Ragu, 1995 & 219 & 45 & 2000 & 817000 \\
LOICZ: Milliman et al., 1995 & 401 & 112 & 110 & 810000 \\
Jansson, 1988 & $1358^{2}$ & 445 & $>300^{3}$ & N.A. \\
de Araujo and Knight, 2005 & 364 & 55 & $>0.014$ & $<10000^{4}$ \\
Dedkov and Gusarov, 2006 & 4140 & N.A. & N.A. & N.A. \\
FAO, 2008 & 869 & 123 & 100 & 1800000 \\
\hline
\end{tabular}

N.A.: not available. ${ }^{1}$ : Actual $\min$ and $\max A$ unknown. Authors only report that the presented global $S Y$-map aims to represent the $S Y$ of basins of $1000-10000 \mathrm{~km}^{2} .{ }^{2}$ : \# Entries for Europe does not include soviet union. From the publication it was unclear which 188 entries of the soviet union are situated in Europe. ${ }^{3}: 300 \mathrm{~km}^{2}$ is the minimum $A$ for the global dataset. The $\min A$ for the European data could not be estimated. ${ }^{4}:$ min. and max. A estimated from figure in publication. 
Table 2: Overview of the collected $S Y$-data. For each country, the number of gauging stations (GS) and reservoir (R) entries, the corresponding number of catchment-years, and the sources of the data are indicated.

\begin{tabular}{|c|c|c|c|c|}
\hline County & $\begin{array}{l}\text { \#GS-antrias } \\
\text { (catch. } \mathrm{yr} \text { ) }\end{array}$ & $\begin{array}{l}=\mathbb{R} \text {-entries } \\
\text { (catch yr) }\end{array}$ & $\begin{array}{l}\text { Total }=\text { antrios } \\
\text { (catch. } y z)\end{array}$ & Sourea \\
\hline Albzaia & $11(169)$ & - & $11(169)$ & IAHS (1974): Grazhdnai (2006) \\
\hline Austria & $22(234)$ & $23(446)$ & $45(680)$ & $\begin{array}{l}\text { Schroder and Theuse (1984); Tuchada and Hofar (1990); Habarvack (1996); Banuca and Jordasm } \\
\text { (2000); White (2001); Moybeck ot al. (2003) }\end{array}$ \\
\hline Arserbajian & - & $1(19)$ & $1(19)$ & Golorov (perr commi) \\
\hline $\begin{array}{l}\text { Balaras } \\
\text { Balgiem }\end{array}$ & $36(94)$ & $\begin{array}{c}1(27) \\
22(142)\end{array}$ & $\begin{array}{l}1(27) \\
58(236)\end{array}$ & 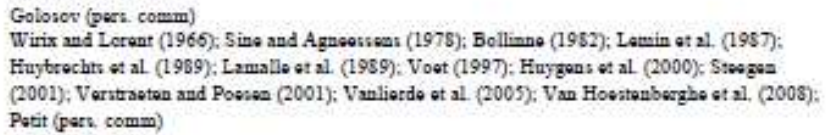 \\
\hline Bosain zod Harzegorian & $4(4)$ & - & $4(4)$ & Joranovic and Vulcovic (1957) \\
\hline Bulgaria & $46(1354)$ & - & $46(1354)$ & Gergov (1996); Trouluili (2002) \\
\hline Croatia & i(1) & - & i(1) & Jovanovic and Vulkcovic (1957) \\
\hline Cypros & - & $7(22)$ & $7(22)$ & Whito (2001) \\
\hline Crech Ropublic & $36(279)$ & $10(315)$ & $45(594)$ & Cybarski (1973); Krasa at al. (2005); Dostal of al. (2006); Becvar (2007); Kadlac ot al. (2007) \\
\hline Doumark & $23(59)$ & - & $23(59)$ & Farbolt (1983); Fuabolt (1991); Labol at al. (1999); Thoduan at al (2004) \\
\hline Evtionia & $I(1)$ & - & $1(1)$ & $\operatorname{RuKZ}$ ot al (2004) \\
\hline Finland & $36(478)$ & - & $36(478)$ & 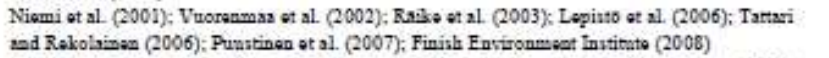 \\
\hline France & $88(360)$ & $13(113)$ & $101(473)$ & 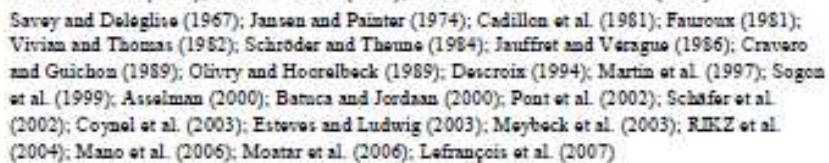 \\
\hline Goorgis & $23(23)$ & - & $23(23)$ & Javibrili $(2002)$ \\
\hline Gernusiny & $129(2065)$ & $17(168)$ & $146(2233)$ & 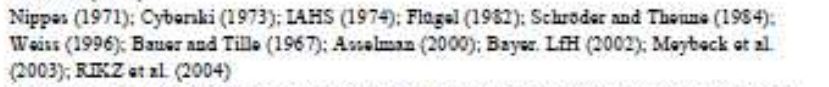 \\
\hline Great Britaiz & $33(\$ 9)$ & $63(4486)$ & $96(+575)$ & 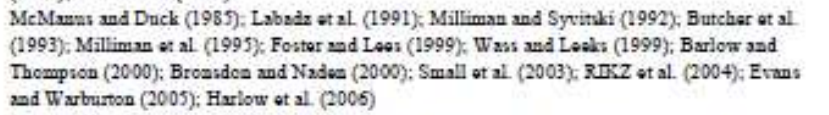 \\
\hline Groece & $13(97)$ & $3(45)$ & $16(142)$ & $\begin{array}{l}\text { Miliman at al. (1995); Poulos ot al (2000); RIxZ at al. (2004); Zaris and Koutsoyimais (2005); } \\
\text { Zaris ot al. (2007) }\end{array}$ \\
\hline Hungary & $25(208)$ & $7(111)$ & $32(319)$ & $\begin{array}{l}\text { Bogurdi (1957); IAHS (1974); Bogurdi ot al. (1983); Siszs ot al. (2007); Cutfordi at al. (2008); } \\
\text { Crafordi ot al. (2009) }\end{array}$ \\
\hline Icolind & $5(73)$ & - & $5(73)$ & Lnwler (1994); Palsson ot al (2000); Old ot al. (2005); Boylich and Knaisel (2009) \\
\hline (Nortbuns) Iroland & $12(12)$ & - & $12(12)$ & RIKZ ot al. (2004); Evass ot al. (2006); Hartington and Harrington (2009) \\
\hline anly & $130(1589)$ & $52(1326)$ & $182(2915)$ & 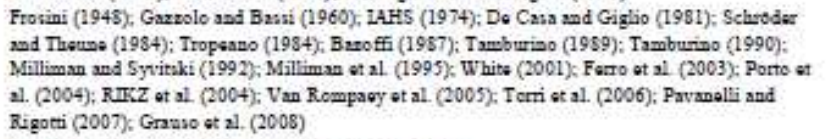 \\
\hline Lithusing & $3(20)$ & - & $3(20)$ & LAHS (1974): Pasteinikovas (1994); RIXZ ot al. (2004) \\
\hline Luxameboug & $5(18)$ & - & $5(18)$ & Verturten (1977); Devijuings (1986); Cummorant (2002); Msrtiner-Curvasas at al. (2010) \\
\hline Macodonia & $3(18)$ & $2(45)$ & $s(63)$ & $\begin{array}{l}\text { Jorswovic and Vukcovic (1957); Skoklavuki and Votichov (1995); Troudafilov (1996); Blinkov } \\
\text { (1998) }\end{array}$ \\
\hline Moldova & $1(2)$ & $1(28)$ & $2(29)$ & RIX $z$ ot al. (2004); Golosor (pen. Comm) \\
\hline Montanegro & $1(1)$ & - & $1(1)$ & Joranovic and Vulkcovic (1957) \\
\hline Nothorlands & $B(48)$ & - & B (48) & IAHS (1974): Vma Dijk and Kwand (1996); RIKZ ot al. (2004) \\
\hline Norway & $49(278)$ & - & $49(278)$ & 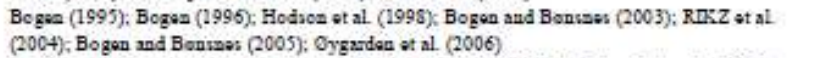 \\
\hline Poland & $63(1794)$ & $23(304)$ & $86(2295)$ & 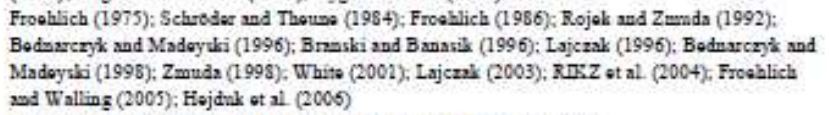 \\
\hline Portugal & $10(35)$ & $5(66)$ & $15(101)$ & DNAG (1997); Millimene ot al (1995), White (2001), RISZ ot al (2004) \\
\hline Rominin & $175(1574)$ & $49(632)$ & $224(2206)$ & Diacona (1969); RIKZ et al. (2004); RSdoume and R.sdonee (2005) \\
\hline $\operatorname{Ransiz}$ & $16(186)$ & $15(568)$ & $31(754)$ & $\begin{array}{l}\text { LAHS (1974); Malliman and Syvituki (1992); Dimitrov ot al (2003); RDKZ ot al (2004); Golovov } \\
\text { (pert comm) }\end{array}$ \\
\hline Saxtis & $7(18)$ & $6(58)$ & $13(76)$ & Jovanovic and Vulcevic (1957); Kontadinov and Markosic (1996); Petkoric ot al. (1999) \\
\hline Slorakia & - & $25(25)$ & $25(25)$ & Januly (1992); Haigh ot al. $(2004)$ \\
\hline Sloverain & $3(4)$ & -1 & $3(4)$ & Jovanovic and Vukcovic (1957) \\
\hline Spain & $17(71)$ & $111(3774)$ & $128(3845)$ & 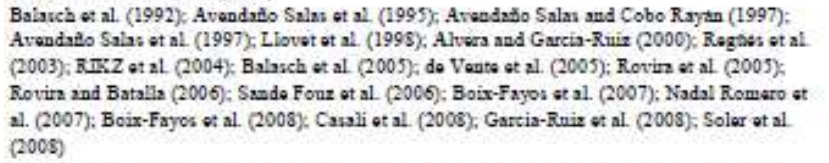 \\
\hline Sweden & $37(554)$ & - & $37(554)$ & $\begin{array}{l}\text { Maliman ot al. (1995); Moybeck et al (2003); Boyjich and Gintz (2004); RחKZ ot al. (2004); } \\
\text { Boyjich ot al. (2005); SMHI (2008) }\end{array}$ \\
\hline Switzorland & $46(649)$ & $28(691)$ & $74(1340)$ & Boyer Portner (1998); Blane at al. (1989); FOWG (2008); Schrodes and Thenwe (1984) \\
\hline Turkey & $162(2952)$ & $16(16)$ & $178(2968)$ & $\begin{array}{l}\text { Miliman at al (1995); Gogtu zod Yever (1997); White (2001); Dimitrov ot al (2003); EEI } \\
\text { (2005) }\end{array}$ \\
\hline Uleraine & $7(42)$ & $7(124)$ & $14(166)$ & $\begin{array}{l}\text { LAHS (1974), Jawisn and Painter (1974); Milliman st al. (1995); Dimitrov ot al (2003); Golosov } \\
\text { (pern comm) }\end{array}$ \\
\hline Total & $1287(15452)$ & $507(13751)$ & $1794(29203)$ & \\
\hline
\end{tabular}


Table 3: Statistical description of the catchment area $\left(A, \mathrm{~km}^{2}\right)$ and sediment yield $\left(S Y, \mathrm{t} \mathrm{km}{ }^{-2}\right.$ $\mathrm{y}^{-1}$ ) for all entries per measuring method (gauging stations (GS) or reservoirs (R)), climatic region (see Fig. 1) and topographic zone.

\begin{tabular}{|c|c|c|c|c|c|c|c|c|c|c|c|}
\hline & $\begin{array}{c}\text { number } \\
\text { of obs. }\end{array}$ & $\min$ & median & $\begin{array}{l}\mathrm{A}\left(\mathrm{km}^{2}\right) \\
\text { mean }\end{array}$ & $\max$ & Std. & $\min$ & median & $\begin{array}{c}\mathrm{SY}\left(\mathrm{t} \mathrm{km}^{-2} \mathrm{y}^{-1}\right) \\
\text { mean }\end{array}$ & $\max$ & Std. \\
\hline \multicolumn{12}{|l|}{ All SY data } \\
\hline All data & 1794 & 0.01 & 791 & 14460 & 1360000 & 76683 & 0.3 & 92 & 341 & 30000 & 1113 \\
\hline All GS data & 1287 & 0.01 & 1193 & 12660 & 1350659 & 54592 & 0.4 & 63 & 279 & 30000 & 1162 \\
\hline All R data & 507 & 0.01 & 148 & 19027 & 1360000 & 115036 & 0.3 & 227 & 498 & 12000 & 959 \\
\hline \multicolumn{12}{|l|}{ SY data: per Climatic Zone } \\
\hline Alpine & 157 & 0.30 & 203 & 764 & 10550 & 1480 & 0.9 & 198 & 451 & 8990 & 876 \\
\hline Anatolian & 70 & 43.50 & 3417 & 6343 & 36642 & 8352 & 1.4 & 144 & 366 & 4299 & 683 \\
\hline Arctic & 7 & 0.70 & 7 & 15 & 33 & 15 & 27.9 & 98 & 148 & 359 & 126 \\
\hline Atlantic & 282 & 0.10 & 135 & 10199 & 163896 & 27764 & 0.4 & 28 & 100 & 2834 & 243 \\
\hline Boreal & 93 & 0.10 & 2054 & 17356 & 229000 & 36281 & 0.5 & 6 & 40 & 1256 & 141 \\
\hline Continental & 608 & 0.04 & 1147 & 19668 & 1280000 & 92648 & 0.5 & 70 & 177 & 4678 & 338 \\
\hline Mediterranean & 540 & 0.01 & 722 & 5189 & 97800 & 14197 & 0.3 & 218 & 673 & 30000 & 1863 \\
\hline Steppic & 37 & 48.00 & 9700 & 165574 & 1360000 & 330504 & 1.8 & 60 & 281 & 1980 & 419 \\
\hline \multicolumn{12}{|l|}{ SY data: per Topographic Zone } \\
\hline Lowland $(0-100 \mathrm{~m})$ & 413 & 0.01 & 2096 & 40518 & 1360000 & 138111 & 0.5 & 35 & 232 & 8990 & 657 \\
\hline Hills $(100-500 \mathrm{~m})$ & 842 & 0.04 & 762 & 9588 & 1210000 & 52168 & 0.4 & 84 & 271 & 4678 & 495 \\
\hline Low Mountain Ranges (500-1500m) & 434 & 0.01 & 582 & 2302 & 50068 & 5246 & 0.3 & 174 & 568 & 30000 & 2018 \\
\hline High Mountain Ranges $(1500-2500 \mathrm{~m})$ & 101 & 0.06 & 195 & 1286 & 27251 & 3392 & 0.9 & 150 & 385 & 3865 & 629 \\
\hline Alpine Mountain Ranges $(2500-5000 \mathrm{~m})$ & 4 & 24.50 & 56 & 1075 & 4162 & 2058 & 40.8 & 204 & 431 & 1274 & 567 \\
\hline
\end{tabular}


Table 4: Regression results of all Sediment Yield $(S Y)$ - Catchment Area $(A)$ relationships. \# entries indicates the number of observations, \# catch. yr. is the total number of catchment year data, $\mathrm{a}$ and $\mathrm{b}$ are the regression coefficients of the equation $S Y=\mathrm{a} A^{\mathrm{b}}, \quad \mathrm{p}$ indicates the significance level of the exponent (values in italic mean that the equation is insignificant at a significance level of $\alpha=0.05$ ). The weighted regression section presents the results of the regressions where all observations are weighted according to the square root of their measuring period.

\begin{tabular}{|c|c|c|c|c|c|c|c|c|c|c|c|}
\hline & \multirow{2}{*}{ Data Groups } & \multirow{2}{*}{$\begin{array}{c}\# \\
\text { entries }\end{array}$} & \multirow{2}{*}{$\begin{array}{c}\# \\
\text { catch.yr. }\end{array}$} & \multicolumn{4}{|c|}{ Normal regression } & \multicolumn{4}{|c|}{ Weighted regression } \\
\hline & & & & a & $\mathrm{b}$ & $\mathrm{p}$ & $r^{2}$ & a & $\mathrm{b}$ & $\mathrm{p}$ & $r^{2}$ \\
\hline I & All data & & & & & & & & & & \\
\hline I.1 & All catchments & 1794 & 29203 & 167.1 & -0.11 & $<0.001$ & 0.04 & 160.7 & -0.11 & $<0.001$ & 0.03 \\
\hline I. 2 & All Gauging Stations & 1287 & 15452 & 121.1 & -0.10 & $<0.001$ & 0.03 & 158.2 & -0.13 & $<0.001$ & 0.04 \\
\hline I. 3 & All Reservoirs & 507 & 13751 & 193.8 & -0.02 & 0.401 & 0.00 & 132.5 & 0.01 & 0.535 & 0.00 \\
\hline I.4 & All catchments $<100 \mathrm{~km}^{2}$ & 444 & 8597 & 114.0 & -0.04 & 0.348 & 0.00 & 85.9 & 0.06 & 0.179 & 0.00 \\
\hline I. 5 & All catchments $100-10000 \mathrm{~km}^{2}$ & 1065 & 16673 & 440.1 & -0.23 & $<0.001$ & 0.02 & 673.1 & -0.28 & $<0.001$ & 0.04 \\
\hline I.6 & All catchments > $10000 \mathrm{~km}^{2}$ & 285 & 3933 & 2293.2 & -0.40 & $<0.001$ & 0.06 & 952.4 & -0.33 & 0.000 & 0.05 \\
\hline II & River Catchments & & & & & & & & & & \\
\hline II.1 & Danube & 389 & 4684 & 254.1 & -0.11 & $<0.001$ & 0.04 & 264.2 & -0.11 & $<0.001$ & 0.04 \\
\hline II. 2 & Ebro & 23 & 693 & 90.7 & 0.06 & 0.641 & 0.01 & 113.9 & 0.06 & 0.681 & 0.01 \\
\hline II. 3 & Elbe & 58 & 651 & 97.8 & -0.28 & $<0.001$ & 0.32 & 97.5 & -0.27 & $<0.001$ & 0.34 \\
\hline II. 4 & Oder & 25 & 657 & 87.9 & -0.24 & 0.009 & 0.26 & 170.9 & -0.31 & 0.003 & 0.33 \\
\hline III. 5 & Ouse & 42 & 3358 & 65.6 & -0.10 & 0.223 & 0.04 & 46.3 & 0.05 & 0.733 & 0.00 \\
\hline II. 6 & Po & 50 & 819 & 244.1 & 0.01 & 0.942 & 0.00 & 158.5 & 0.07 & 0.443 & 0.01 \\
\hline II. 7 & Rhine & 115 & 1712 & 169.9 & -0.17 & 0.001 & 0.10 & 397.6 & -0.25 & $<0.001$ & 0.17 \\
\hline II 8 & Rhône & 58 & 529 & 1590.6 & -0.28 & $<0.001$ & 0.38 & 2242.4 & -0.29 & $<0.001$ & 0.43 \\
\hline II. 9 & Schelde & 40 & 129 & 210.8 & -0.21 & 0.013 & 0.15 & 255.2 & -0.25 & 0.005 & 0.19 \\
\hline П П.10 & Segura & 28 & 1065 & 116.6 & 0.07 & 0.245 & 0.05 & 118.5 & 0.08 & 0.151 & 0.08 \\
\hline ПП.11 & Vistula & 55 & 1470 & 450.6 & -0.31 & $<0.001$ & 0.21 & 691.2 & -0.37 & $<0.001$ & 0.27 \\
\hline III & All data per Climatic Regions & & & & & & & & & & \\
\hline IIII.1 & Alpine & 157 & 2267 & 247.3 & -0.09 & 0.164 & 0.01 & 264.3 & -0.07 & 0.329 & 0.01 \\
\hline IIII. 2 & Anatolian & 70 & 1183 & 102.2 & 0.02 & 0.880 & 0.00 & 15.4 & 0.24 & 0.049 & 0.06 \\
\hline IIII. 3 & Arctic & 7 & 26 & 45.2 & 0.42 & 0.087 & 0.47 & 55.5 & 0.42 & 0.063 & 0.53 \\
\hline IIII.4 & Atlantic & 282 & 5668 & 64.4 & -0.13 & $<0.001$ & 0.10 & 64.1 & -0.11 & $<0.001$ & 0.09 \\
\hline IIII. 5 & Boreal & 93 & 1489 & 22.1 & -0.14 & 0.001 & 0.11 & 27.6 & -0.15 & 0.001 & 0.12 \\
\hline IIII.6 & Continental & 608 & 9157 & 170.7 & -0.14 & $<0.001$ & 0.06 & 238.5 & -0.19 & $<0.001$ & 0.09 \\
\hline IIII. 7 & Mediterranean & 540 & 8954 & 298.0 & -0.07 & 0.007 & 0.01 & 247.4 & -0.04 & 0.066 & 0.01 \\
\hline IIII. 8 & Steppic & 37 & 459 & 2494.7 & -0.37 & $<0.001$ & 0.37 & 3371.6 & -0.37 & $<0.001$ & 0.38 \\
\hline III & GS-data per Climatic Region & & & & & & & & & & \\
\hline III.1.GS & Alpine & 98 & 967 & 183.3 & -0.08 & 0.242 & 0.01 & 180.1 & -0.04 & 0.574 & 0.00 \\
\hline III. 2.GS & Anatolian & 62 & 1175 & 7.5 & 0.30 & 0.018 & 0.09 & 6.0 & 0.34 & 0.006 & 0.12 \\
\hline III $3 . \mathrm{GS}$ & Arctic & 7 & 26 & 45.2 & 0.42 & 0.087 & 0.47 & 55.5 & 0.42 & 0.063 & 0.53 \\
\hline III.4.GS & Atlantic & 191 & 939 & 38.3 & -0.08 & 0.010 & 0.04 & 50.6 & -0.10 & $<0.001$ & 0.07 \\
\hline III. 5.GS & Boreal & 85 & 1060 & 23.8 & -0.18 & $<0.001$ & 0.18 & 28.8 & -0.21 & $<0.001$ & 0.25 \\
\hline III.6.GS & Continental & 463 & 7066 & 74.4 & -0.07 & 0.017 & 0.01 & 131.8 & -0.15 & $<0.001$ & 0.05 \\
\hline III. 7.GS & Mediterranean & 356 & 3988 & 342.6 & -0.10 & 0.003 & 0.03 & 310.1 & -0.09 & 0.008 & 0.02 \\
\hline III. $8 . \mathrm{GS}$ & Steppic & 25 & 231 & 1416.5 & -0.34 & 0.006 & 0.28 & 1145.0 & -0.29 & 0.035 & 0.18 \\
\hline III & R-data per Climatic Region & & & & & & & & & & \\
\hline III.1.R & Alpine & 59 & 1300 & 389.3 & -0.08 & 0.506 & 0.01 & 346.0 & -0.06 & 0.623 & 0.00 \\
\hline III. $2 . R$ & Anatolian & 8 & 8 & 498.4 & 0.17 & 0.358 & 0.14 & 498.4 & 0.17 & 0.358 & 0.14 \\
\hline III. $3 . R$ & Arctic & 0 & 0 & - & - & - & - & - & - & - & - \\
\hline III. $4 . R$ & Atlantic & 91 & 4729 & 66.6 & 0.05 & 0.605 & 0.00 & 46.0 & 0.14 & 0.183 & 0.02 \\
\hline III. $5 . R$ & Boreal & 8 & 429 & 357.8 & -0.24 & 0.062 & 0.47 & 385.4 & -0.24 & 0.033 & 0.56 \\
\hline III.6.R & Continental & 145 & 2091 & 443.4 & -0.15 & $<0.001$ & 0.11 & 498.5 & -0.18 & $<0.001$ & 0.13 \\
\hline III.7.R & Mediterranean & 184 & 4966 & 237.7 & 0.00 & 0.913 & 0.00 & 200.0 & 0.01 & 0.780 & 0.00 \\
\hline III. $8 . R$ & Steppic & 12 & 228 & 42915.1 & -0.57 & $<0.001$ & 0.79 & 45611.0 & -0.57 & $<0.001$ & 0.80 \\
\hline IV & All data per Topographic Region & & & & & & & & & & \\
\hline IV.1 & Lowland $(0-100 \mathrm{~m})$ & 413 & 4630 & 143.5 & -0.17 & $<0.001$ & 0.09 & 168.1 & -0.19 & $<0.001$ & 0.11 \\
\hline IV.2 & Hills $(100-500 \mathrm{~m})$ & 842 & 14919 & 112.5 & -0.05 & 0.007 & 0.01 & 101.4 & -0.05 & 0.013 & 0.01 \\
\hline IV.3 & Low Mountain Range (500-1500m) & 434 & 7605 & 198.4 & -0.06 & 0.060 & 0.01 & 182.8 & -0.04 & 0.204 & 0.00 \\
\hline IV.4 & High Mountain Range (1500-2500m) & 101 & 1917 & 168.2 & -0.05 & 0.376 & 0.01 & 158.3 & -0.03 & 0.577 & 0.00 \\
\hline IV.5 & Alpine Mountain Range $(2500-5000 \mathrm{~m})$ & 4 & 132 & 202.0 & 0.01 & 0.979 & 0.00 & 310.8 & -0.03 & 0.952 & 0.00 \\
\hline
\end{tabular}


Table 5: Number of entries for each climatic region (see Fig. 1), subdivided according to the measuring method (gauging station (GS) or reservoir (R)) and topographic zone.

\begin{tabular}{ccccccccc}
\hline Climatic Zone & Total & \multicolumn{2}{c}{$\begin{array}{c}\text { Measuring method } \\
\text { GS }\end{array}$} & & R & Lowlands & $\begin{array}{c}\text { Topographic region } \\
\text { Hills }\end{array}$ & Low Mnt. High Mnt. Alpine Mnt. \\
\hline Alpine & 157 & 98 & 59 & 2 & 19 & 75 & 58 & 3 \\
Anatolian & 70 & 62 & 8 & 0 & 1 & 49 & 19 & 1 \\
Arctic & 7 & 7 & 0 & 0 & 4 & 0 & 0 & 0 \\
Atlantic & 282 & 191 & 91 & 145 & 134 & 3 & 0 & 0 \\
Boreal & 93 & 85 & 8 & 62 & 29 & 2 & 0 & 0 \\
Continental & 608 & 463 & 145 & 72 & 407 & 129 & 0 & 0 \\
Mediterranean & 540 & 356 & 184 & 106 & 234 & 176 & 24 & 0 \\
Steppic & 37 & 25 & 12 & 26 & 11 & 0 & 0 & 0 \\
\hline
\end{tabular}




\section{Figures:}

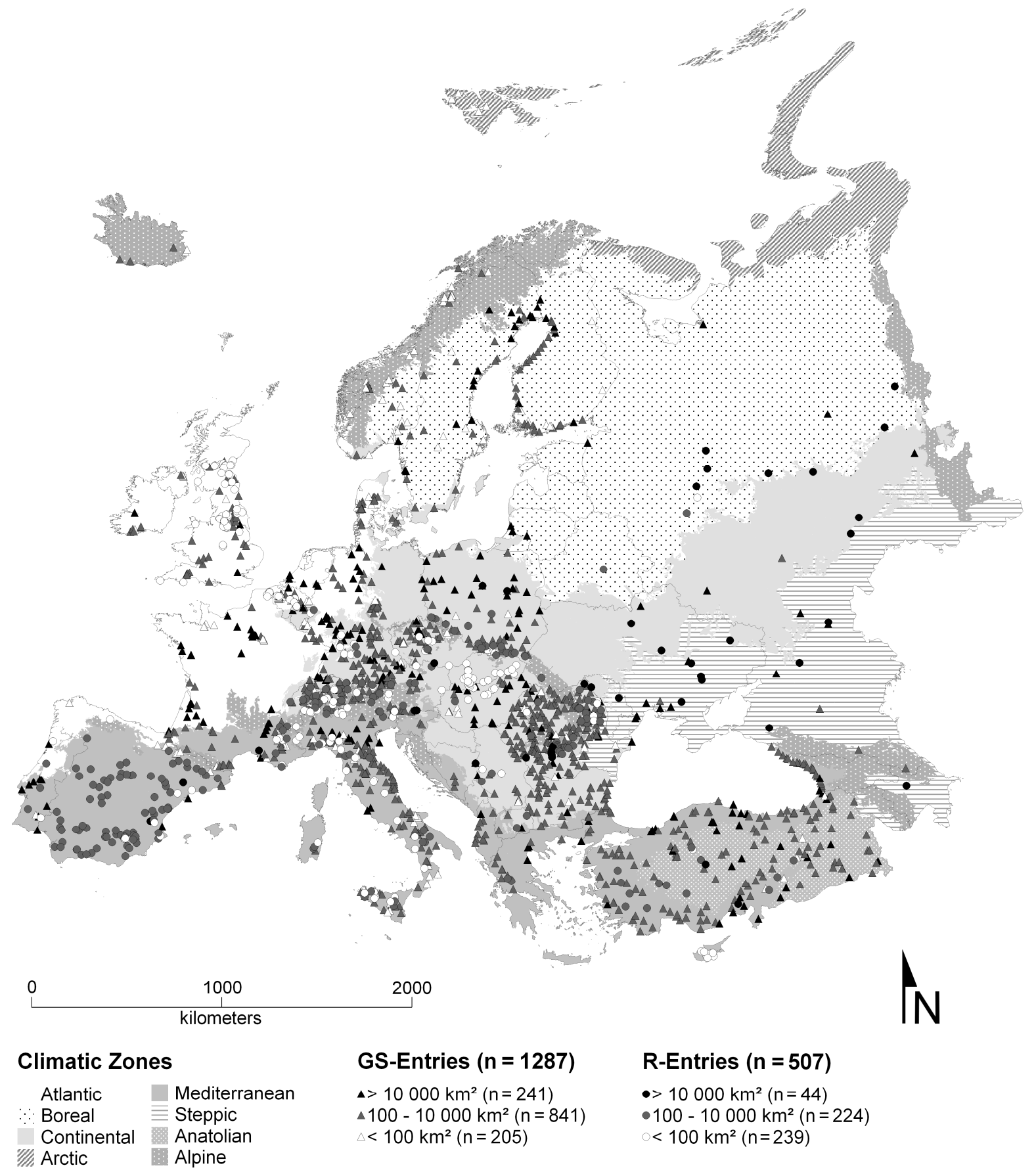

Fig. 1: Study area and location of all catchment outlets (gauging stations (GS) and reservoir (R)) in the $S Y$-database. Climatic regions were derived from the LANMAP2 database (Mücher et al., 2006; Metzger et al., 2005). 


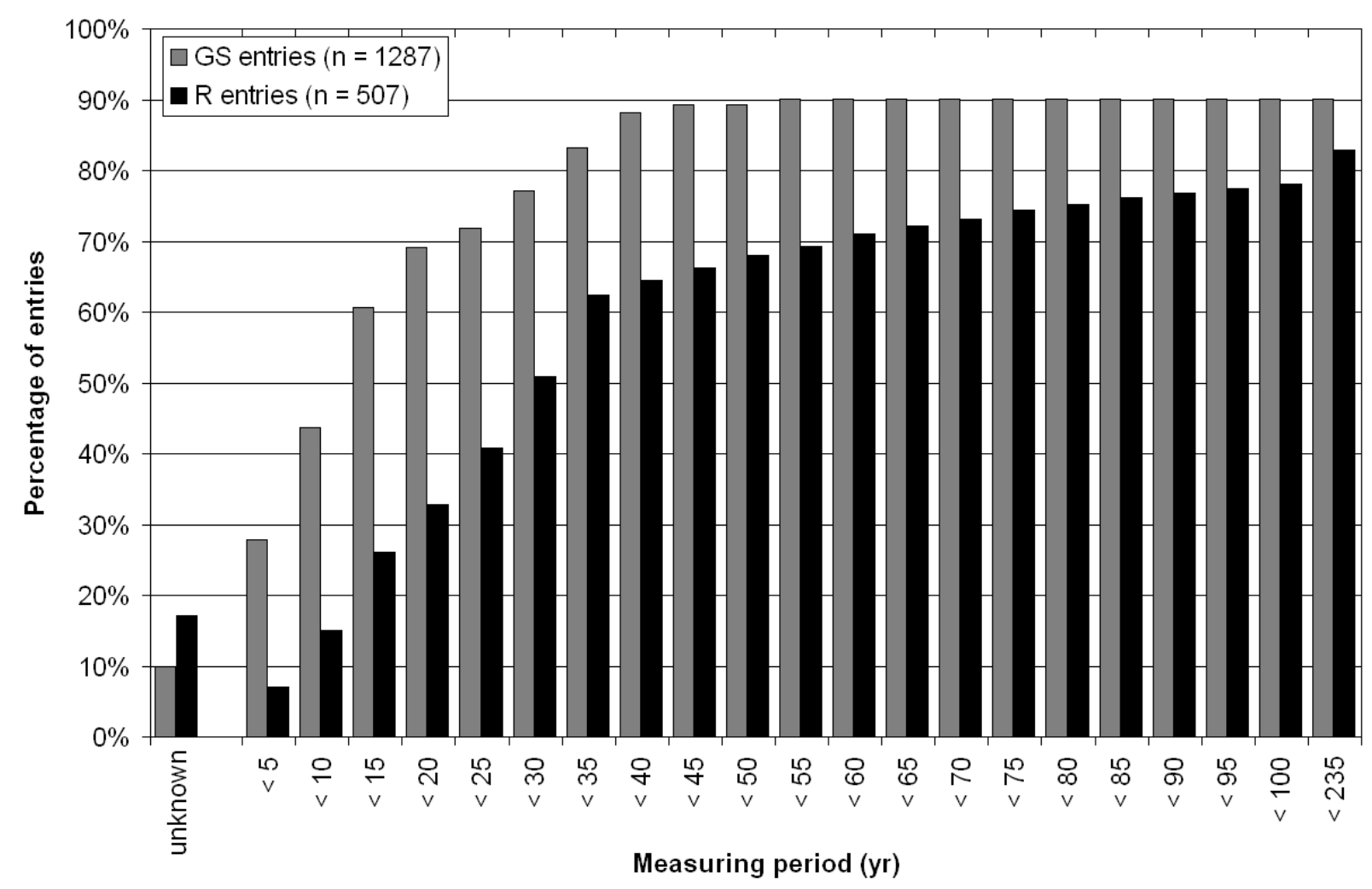

Fig. 2: Cumulative distribution of the gauging stations (GS) and reservoir (R) entries according to the duration of their measuring period. 

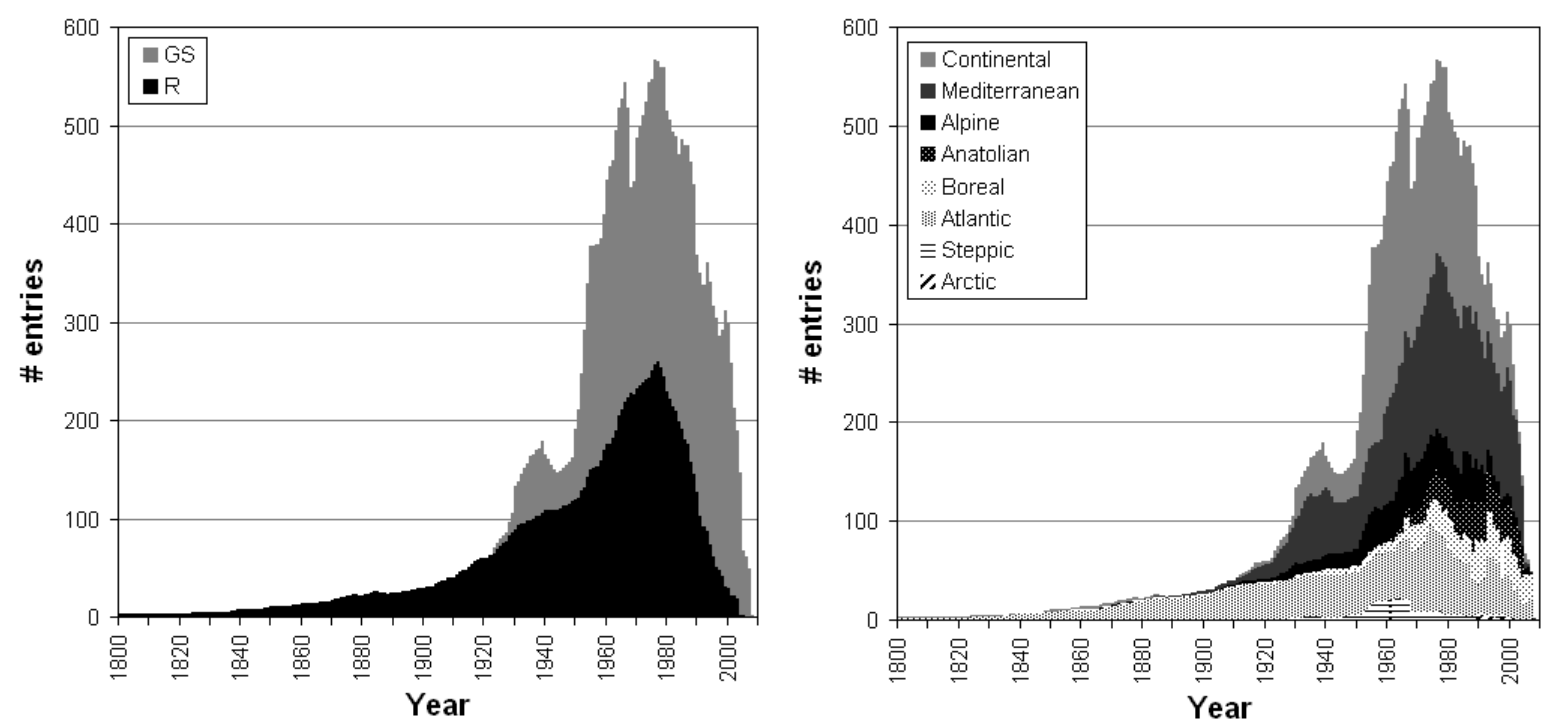

Fig. 3: Temporal coverage of the entries with a known start and end date $(n=1490)$ according to their measuring method (gauging stations (GS) and reservoirs (R)) (left) and climatic region (right). '\# entries' indicates the number of entries in the database that include a certain year in their measuring period. 

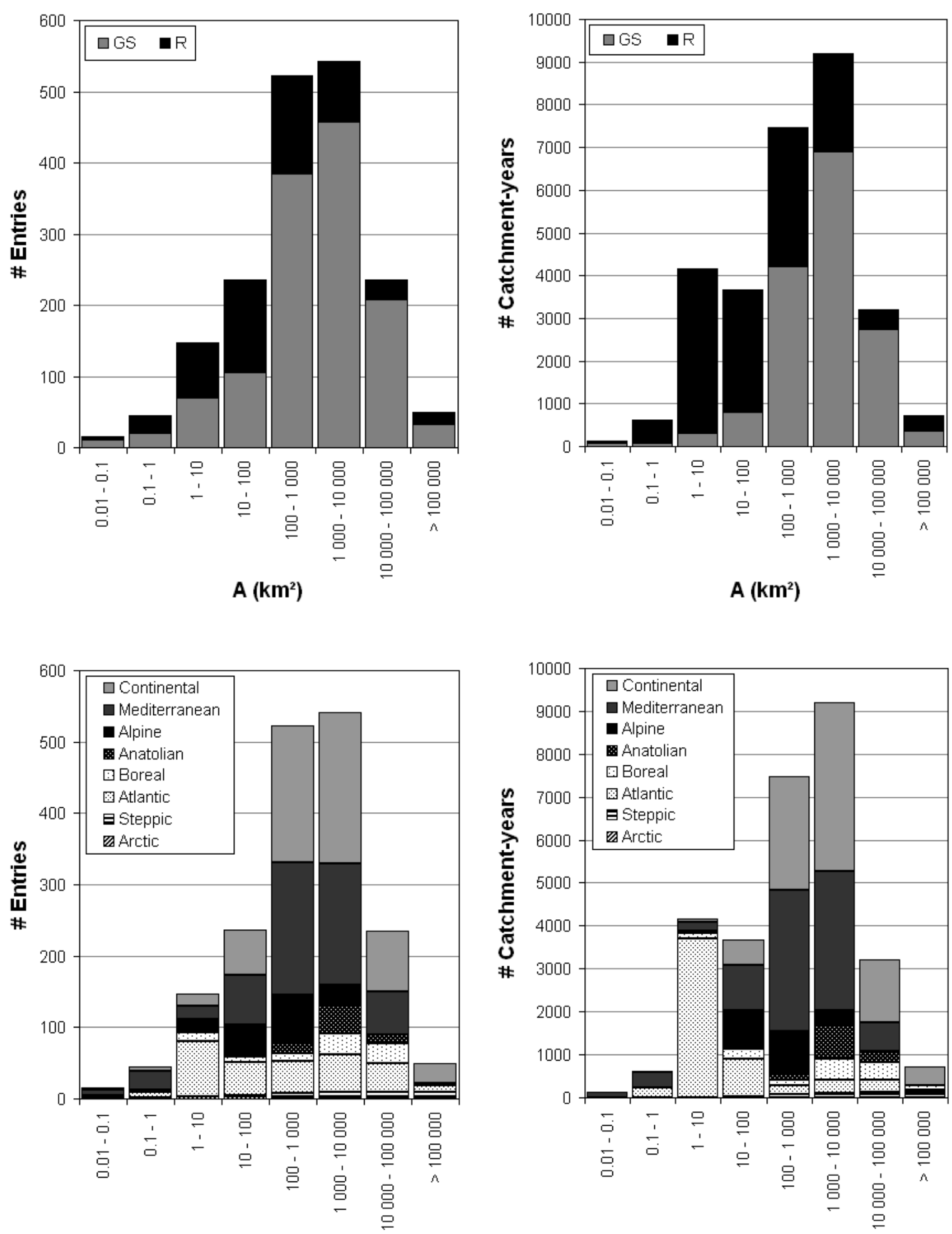

$A\left(\mathbf{k m}^{2}\right)$

$\mathbf{A}\left(\mathbf{k m}^{2}\right)$

Fig. 4: Frequency distribution of the number of entries (left) and number of catchment-year data (right) according to catchment area $(A)$. A subdivision is made according the measuring method (top; GS: gauging station, R: reservoir) and according to climatic region (bottom, see Fig. 1). 


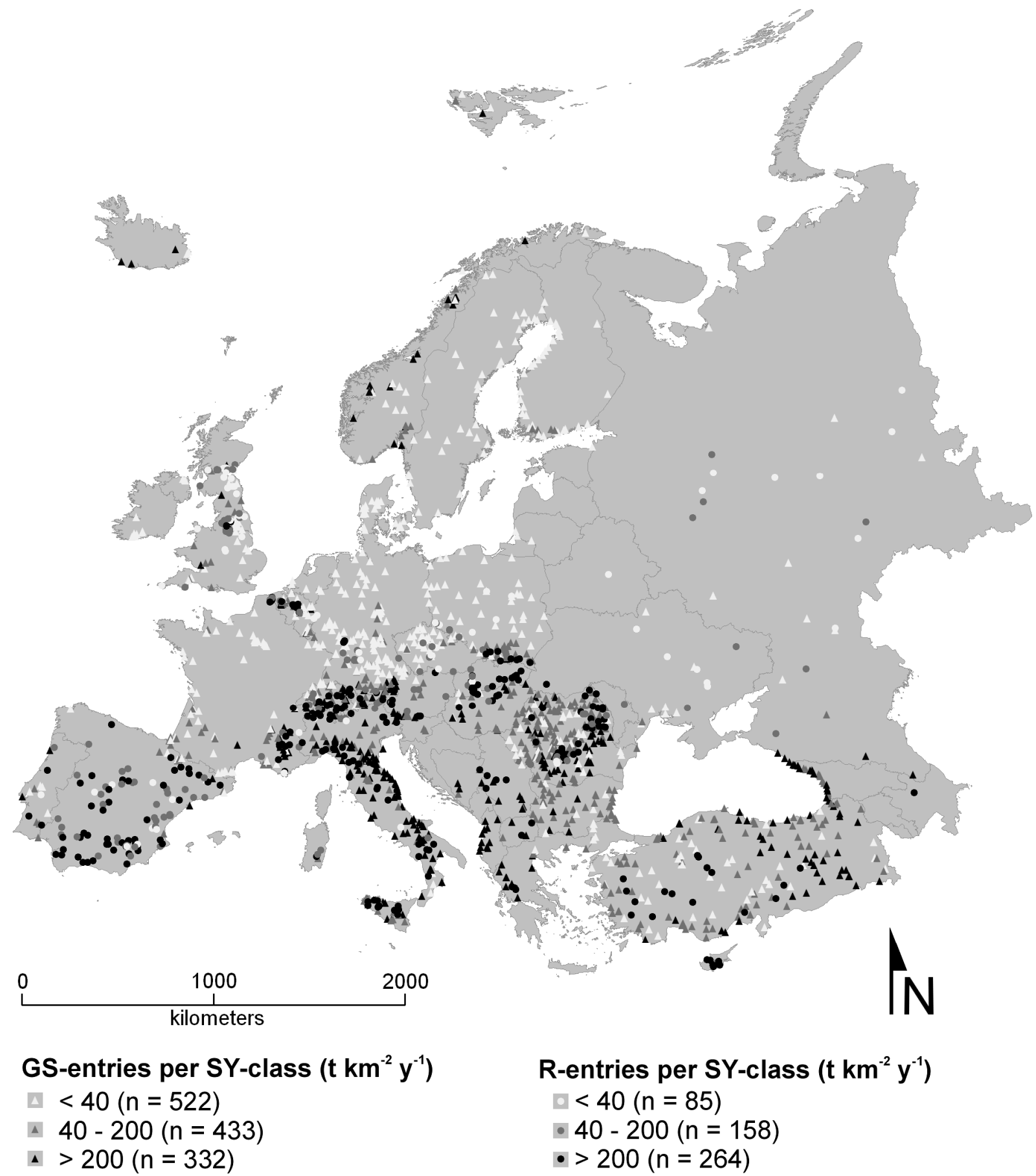

Fig. 5: Sediment yield (SY) map of Europe based on all gauging station (GS) and reservoir (R) data. 

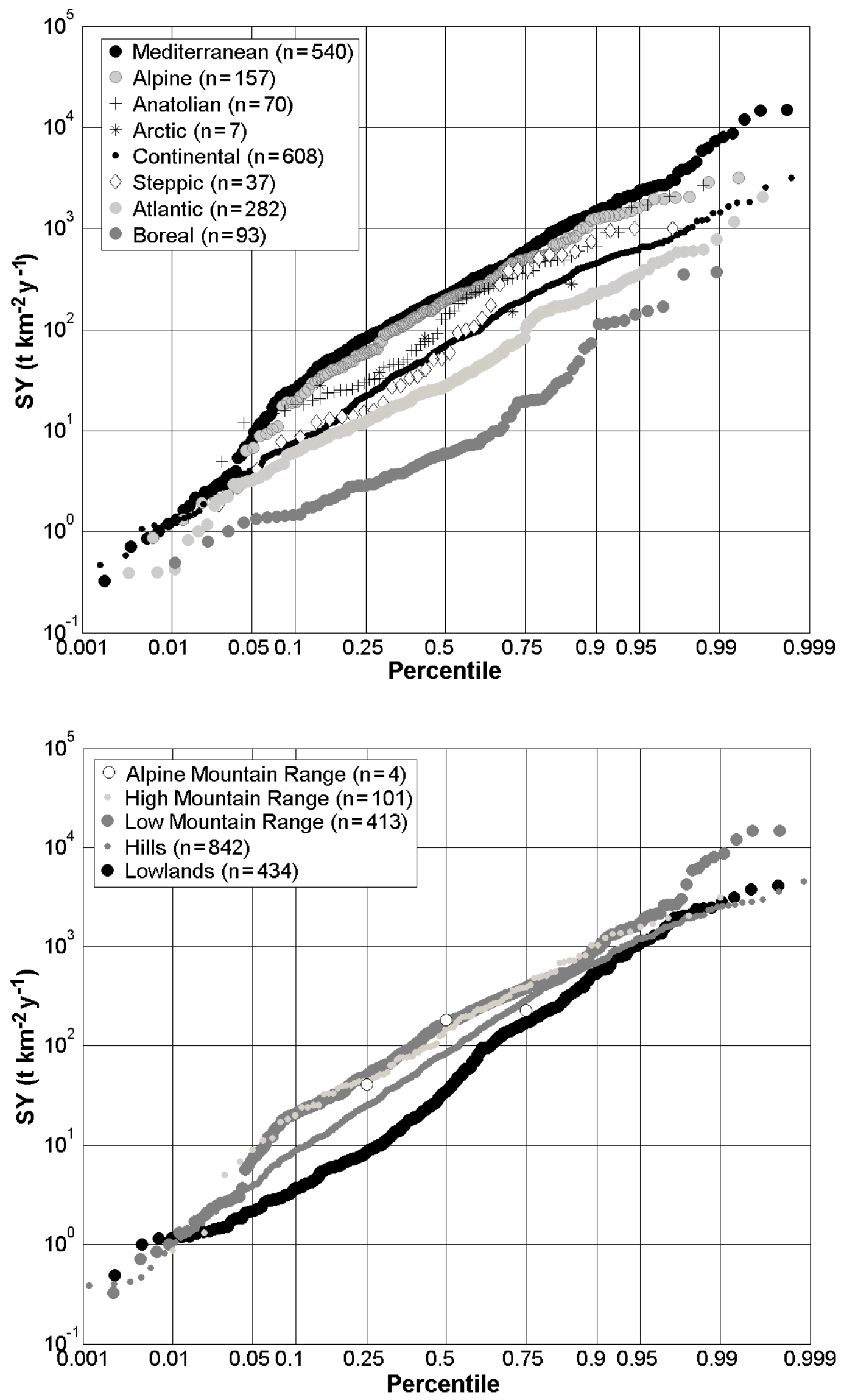

Fig. 6: Cumulative frequency distribution of the $S Y$-values for all data, classified according to climatic region (top, see Fig. 1) and topographic zone (bottom). 


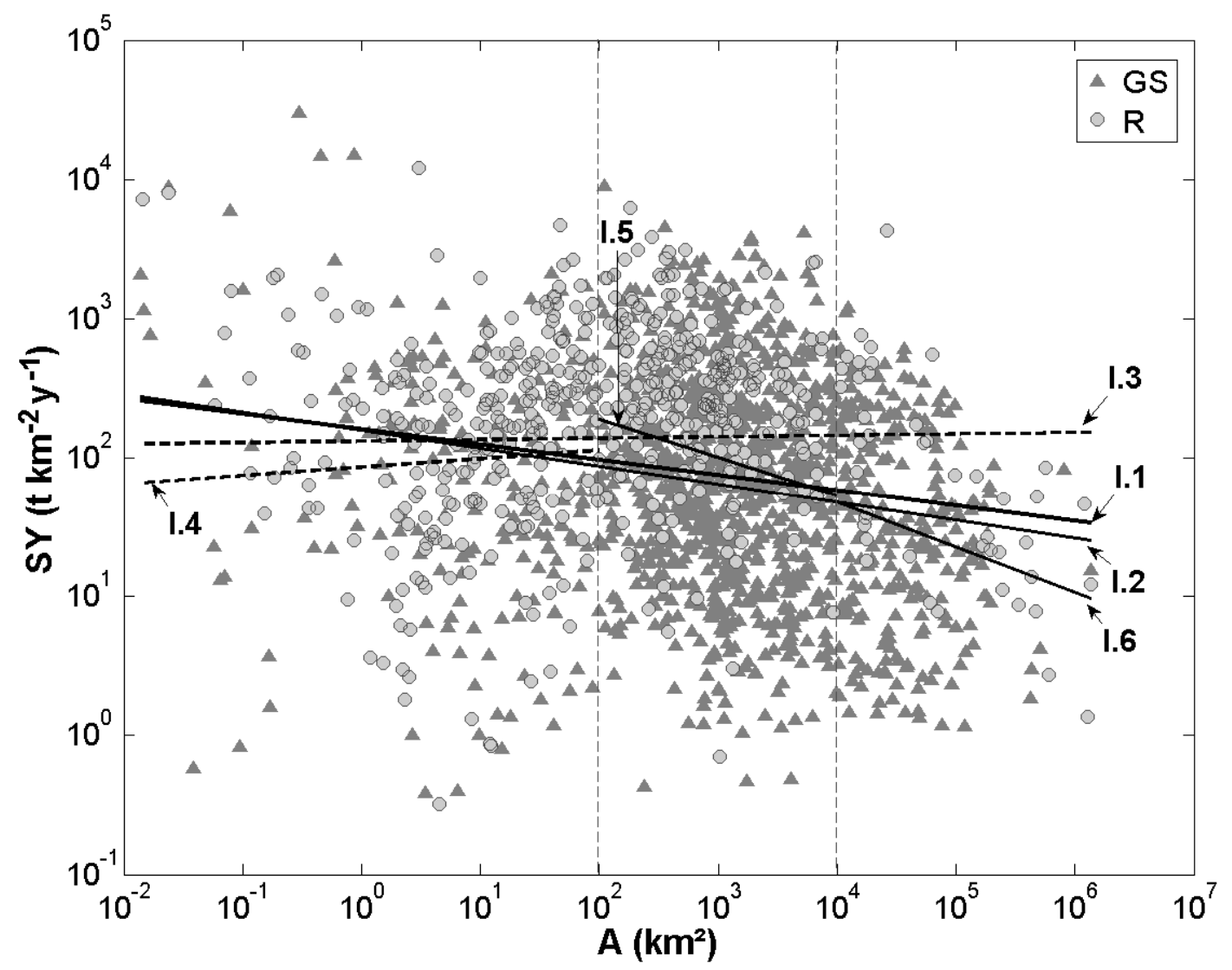

Fig. 7: Sediment Yield $(S Y)$ - Catchment Area $(A)$ relationships for all data, weighted according to the length of the measuring period (see text). Dashed lines are insignificant at $\alpha=0.05$. I.1: All data, I.2: All gauging station (GS) data, I.3: All reservoir (R) data, I.4: All catchments < $100 \mathrm{~km}^{2}$, I.5: All catchments $100-10000 \mathrm{~km}^{2}$, I.6: All catchments > 10000 $\mathrm{km}^{2}$. For details on the regression equations: see Table 4 (weighted regressions). 


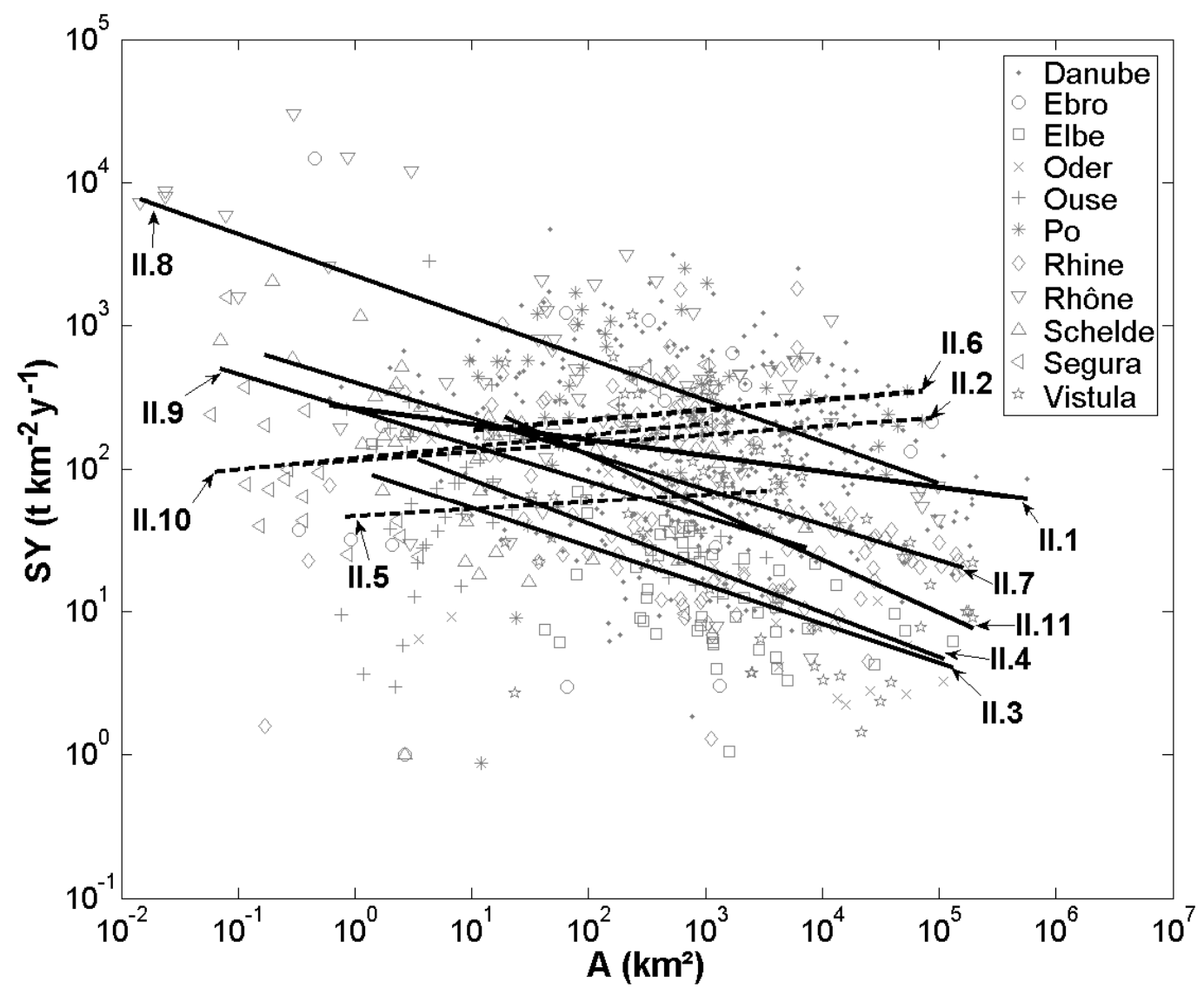

Fig. 8: Sediment Yield $(S Y)$ - Catchment Area $(A)$ relationships, grouped by river catchment and weighted according to the length of the measuring period. Dashed lines are insignificant at $\alpha=0.05$. II.1: Danube, II.2: Ebro, II.3: Elbe, II.4: Oder, II.5: Ouse, II.6: Po, II.7: Rhine, II.8: Rhône, II.9: Schelde, II.10: Segura, II.11: Vistula. For details on the regression equations: see Table 4 (weighted regressions). 


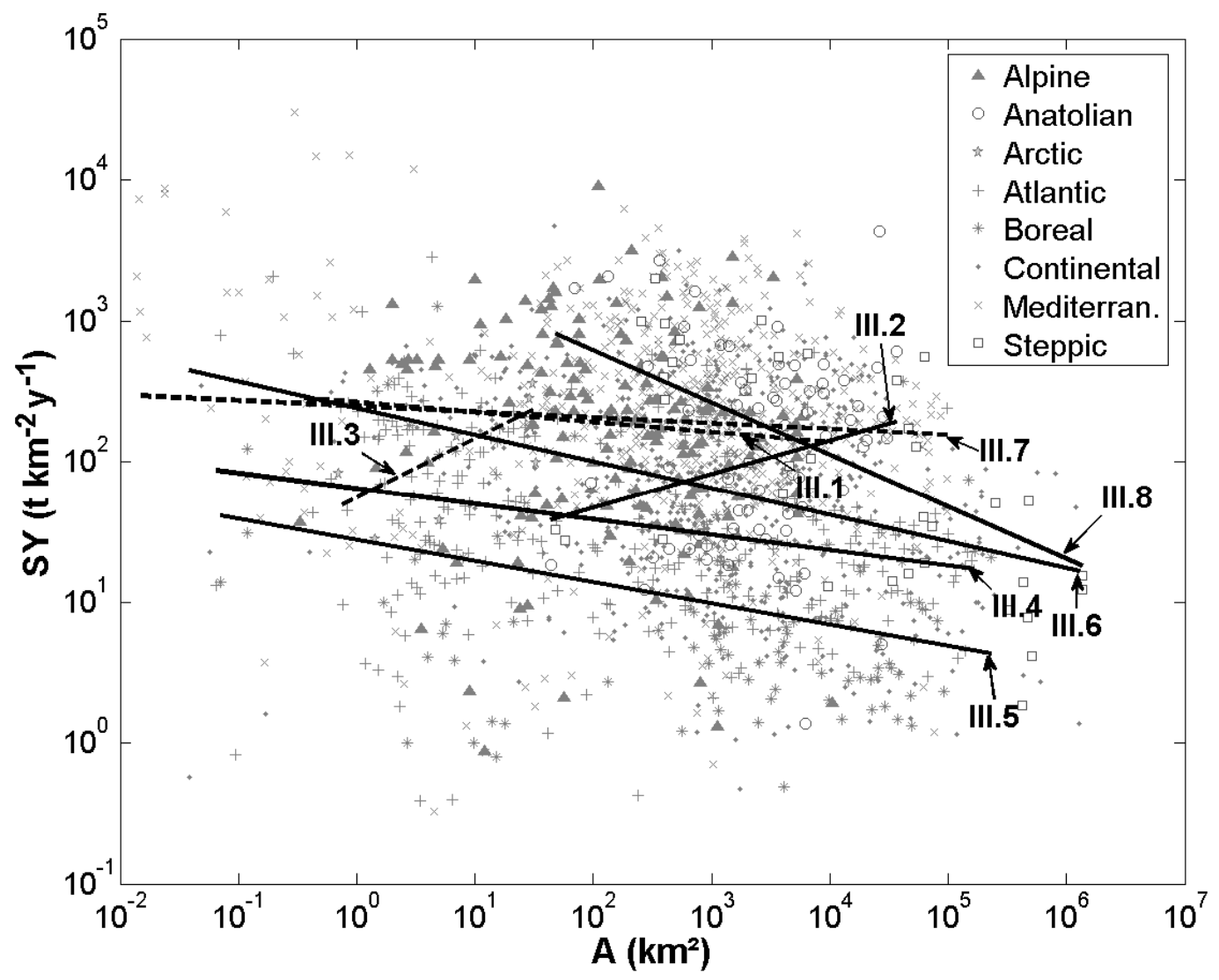

Fig. 9: Sediment Yield $(S Y)$ - Catchment Area $(A)$ relationships for all data, grouped by climatic region (see Fig. 1) and weighted according to the length of the measuring period. Dashed lines are insignificant at $\alpha=0.05$. III.1: Alpine, III.2: Anatolian, III.3: Arctic, III.4: Atlantic, III.5: Boreal, III.6: Continental, III.7: Mediterranean, III.8: Steppic. For details on the regression equations: see Table 4 (weighted regressions). 

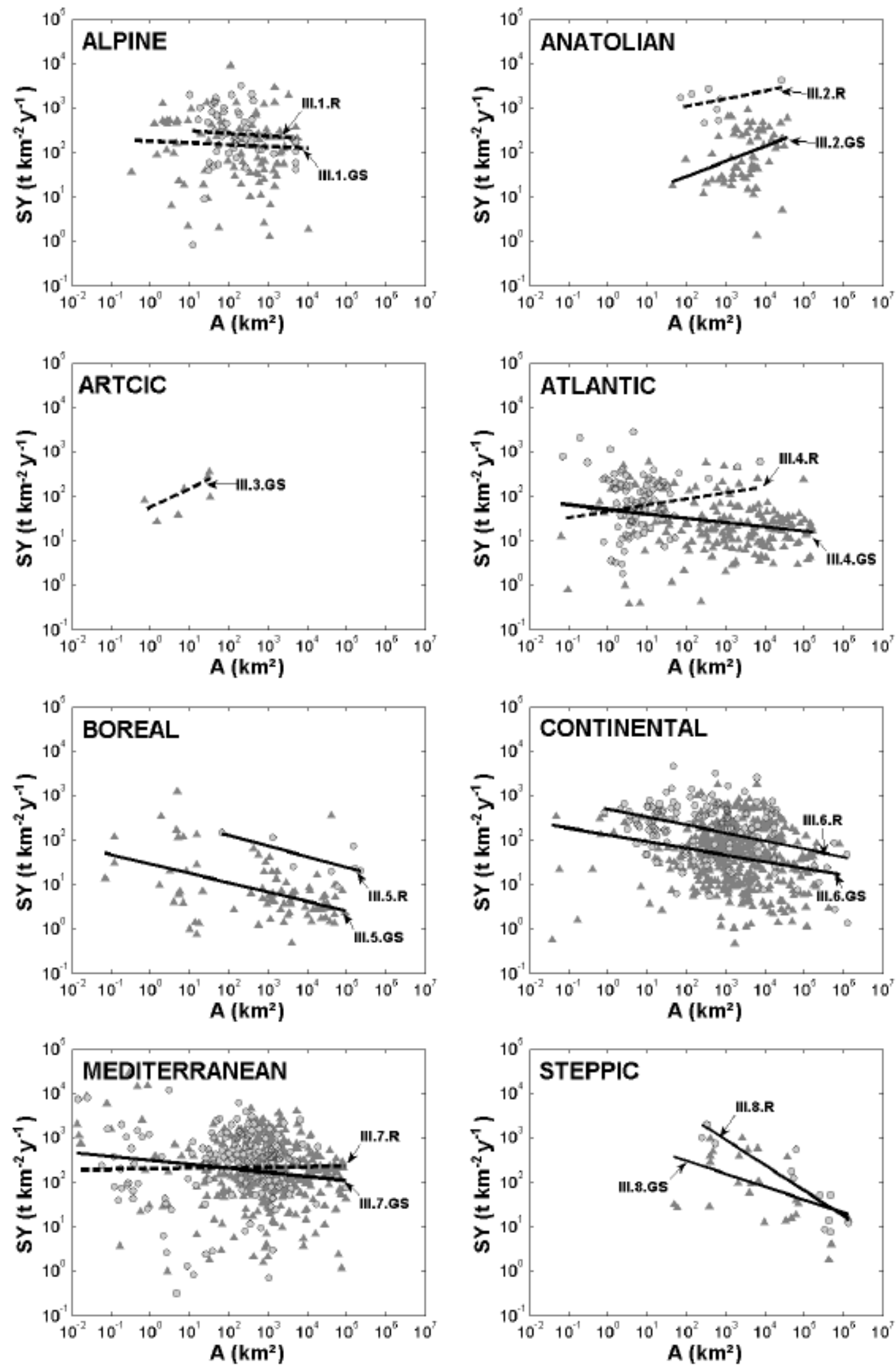

Fig. 10: Sediment Yield $(S Y)$ - Catchment Area $(A)$ relationships per climatic region (see Fig. 1), subdivided according to measuring method. Circles represent reservoir (R) data; triangles represent gauging station (GS) data. For details on the regression equations: see Table 4 (weighted regressions). 


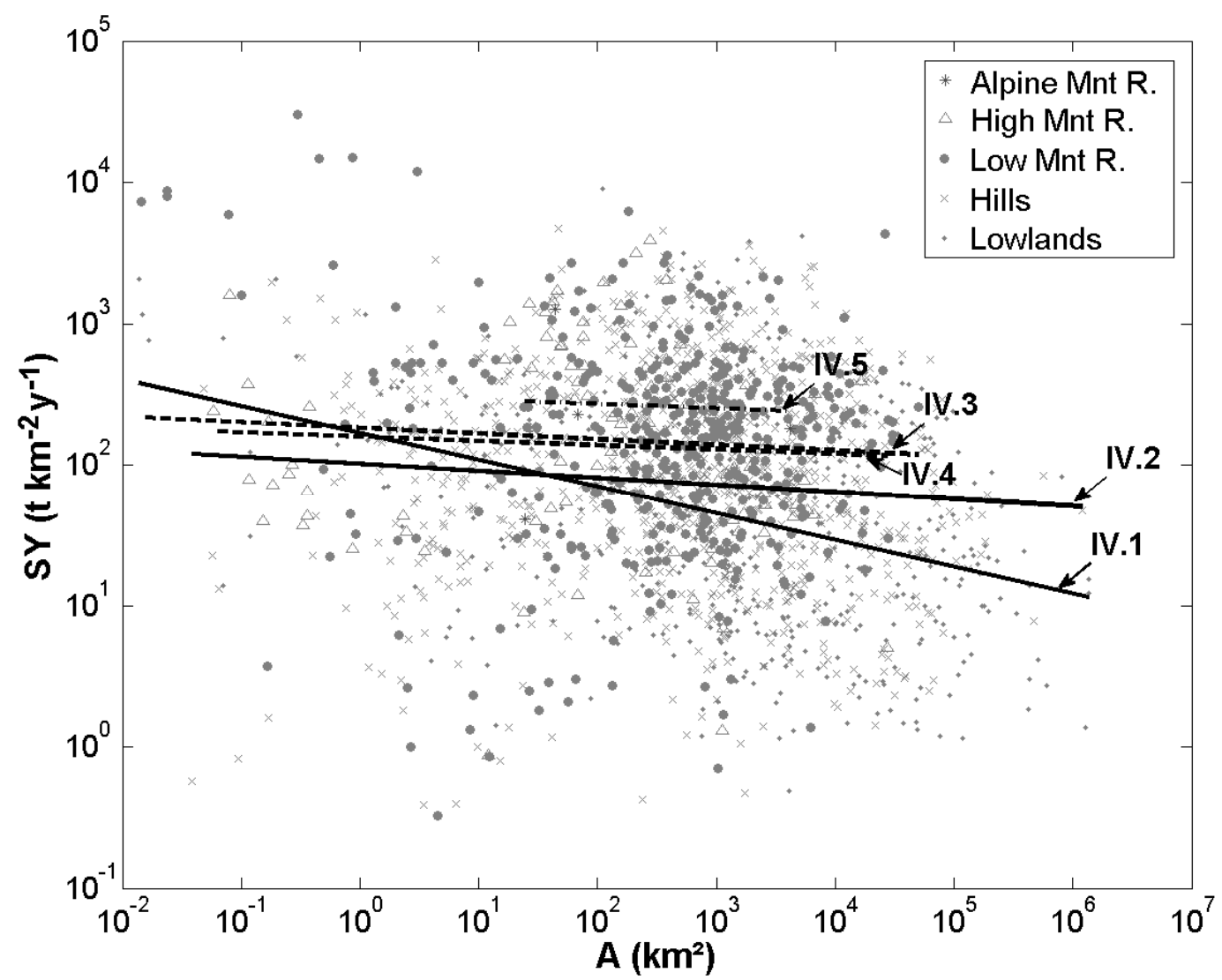

Fig. 11: Sediment Yield $(S Y)$ - Catchment Area $(A)$ relationships for all data, grouped by topographic zone of the measuring location and weighted according to the length of the measuring period. Dashed lines are insignificant at $\alpha=0.05$. IV.1: Lowland (0-100m), IV.2: Hills (100-500m), IV.3: Low Mountain Range (500-1500m), IV.4: High Mountain Range (1500-2500m), IV.5: Alpine Mountain Range (2500-5000m). For details on the regression equations: see Table 4 (weighted regressions). 